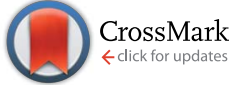

Cite this: RSC Adv., 2017, 7, 15416

Received 22nd December 2016 Accepted 24th February 2017

DOI: $10.1039 / \mathrm{c} 6 \mathrm{ra} 28584 \mathrm{~h}$

rsc.li/rsc-advances

\title{
Novel triterpenoid derivatives from Eucomis bicolor Bak. (Hyacinthaceae: Hyacinthoideae) $\uparrow$
}

\author{
Jaspreet K. Sihra, ${ }^{a}$ Moses K. Langat, ${ }^{\text {ab }}$ Neil R. Crouch, ${ }^{\text {bc }}$ Jean-Marc Nuzillard, ${ }^{d}$ \\ Bertrand Plainchont ${ }^{d}$ and Dulcie A. Mulholland*ab
}

\begin{abstract}
The bulbs of Eucomis bicolor (Hyacinthoideae) yielded fourteen novel natural compounds, including (17S)3-oxo-24,25,26,27,28-pentanorlanost-8-en-23,17 $\alpha$-olide, whose structure was determined using the logic for structure determination program, and nine novel lanosterol glycosides. Compounds were screened against the $\mathrm{NCl}-59$ cancer cell panel but showed limited activity.
\end{abstract}

\section{Introduction}

The genus Eucomis L'Hér. (Hyacinthaceae sensu APGII: Hyacithoideae) has long been one of the most highly regarded sources of ethnomedicines in southern Africa, a notion based largely on its popularity in informal trade. ${ }^{1-3}$ Eucomis is a small genus of bulbous plants (ten species and fourteen currently accepted taxa), producing inflorescences that are characteristically topped by a conspicuous coma of leafy sterile bracts. ${ }^{3}$ All genus members occur in South Africa, with only two extending to south tropical Africa. The Hyacinthoideae are known to exhibit significant infraspecific chemical variation, depending on the geographical location and season of collection. ${ }^{4-6}$ This prompted the investigation of naturally-sourced Eucomis bicolor Bak. Previous investigations of E. bicolor, purchased from commercial sources in the Netherland $s^{7,8}$ and Japan, ${ }^{9}$ yielded, 5-hydroxy7-methoxy-3-(4'-methoxybenzyl)-4-chromanone, 3,5-dihydroxy7-methoxy-3-(4'-methoxybenzyl)-4-chromanone, ${ }^{8} \quad$ (Z)-5,7-dihydroxy-3-(4'-methoxybenzylidene)-4-chromanone, ${ }^{7}$ six eucosterol oligosaccharide derivatives ${ }^{9}$ and scillasponin A. ${ }^{\mathbf{1 0}}$

\section{Results and discussion}

The current report details the analysis of a collection of Eucomis bicolor Bak. sourced from the foothills of the Drakensberg mountains, KwaZulu-Natal, South Africa. The dichloromethane

${ }^{a}$ Department of Chemistry, Faculty of Engineering and Physical Sciences, University of Surrey, Guildford, GU2 7XH, Surrey, UK. E-mail: d.mulholland@surrey.ac.uk; Tel: +44 (o)1483686751

${ }^{b}$ School of Chemistry and Physics, University of KwaZulu-Natal, Durban, 4041, South Africa

'Biodiversity Economy Unit, South African National Biodiversity Institute, PO Box 52099, Berea Road 4007, Durban, South Africa

${ }^{d}$ Université de Reims Champagne-Ardenne, Institut de Chimie Moléculaire de Reims, CNRS UMR 7312, SFR CAP-Santé, BP 1039, 51687 Reims Cedex 02, France

$\dagger$ Electronic supplementary information (ESI) available. See DOI: $10.1039 / \mathrm{c} 6 \mathrm{ra} 28584 \mathrm{~h}$ extract of Eucomis bicolor yielded thirteen compounds, including three known homoisoflavonoids, 3,5,7-trihydroxy-3(4'-methoxybenzyl)-4-chromanone previously isolated from $E$. bicolor, ${ }^{7}$ Merwilla dracomontana (Hilliard \& B. L. Burtt) Speta (as Scilla dracomontana Hilliard \& B. L. Burtt), ${ }^{11}$ Ledebouria graminifolia (Bak.) Jessop, ${ }^{\mathbf{1 2}}$ Eucomis montana Compton and Resnova humifusa (Baker) U. \& D. M. -D. ${ }^{13}(R)$-5,7-dihydroxy-8-methoxy-3(4'-methoxybenzyl)-4-chromanone previously isolated from Eucomis autumnalis (Mill.) Chitt. subsp. autumnalis and Eucomis comosa (Houtt.) Wehrh. var. comosa ${ }^{14}$ and (R)-5,7-dihydroxy-3(4'-methoxybenzyl)-4-chromanone previously isolated from $E$. bicolor ${ }^{8}$ E. montana, $R$. humifusa,${ }^{13}$ and Ledebouria revoluta (L.f.) Jessop, ${ }^{15}$ four known nortriterpenoids, eucosterol previously isolated from E. autumnalis, ${ }^{16}$ Muscari comosum Mill., ${ }^{17}$ Eucomis pallidiflora Bak. subsp. pole-evansii (N.E.Br.) Reyneke ex J.C. Manning and Eucomis schiiffii Reyneke, ${ }^{3}$ 3-dehydro-15deoxoeucosterol and 15-deoxoeucosterol, previously isolated from Scilla scilloides Druce, ${ }^{18}$ M. comosum,${ }^{17}$ Merwilla plumbea (Lindl.) Speta (as M. natalensis (Planch.) Speta ${ }^{4}$ and Pseudoprospero firmifolium (Baker) Speta, ${ }^{19}$ (23S)-17 $\alpha, 23$-epoxy-3 $\beta, 28,29$ trihydrox-27-norlanost-8-en-24-one, previously isolated from $M$. comosum, ${ }^{20}$ M. plumbea, ${ }^{4}$ E. schiiffi, ${ }^{3}$ and Ledebouria zebrina (Bak.) S. Venter (as Scilla zebrina Bak.) ${ }^{5}$ and 2,4-dimethoxybenzaldehyde, which has not been isolated previously from this family, and five novel triterpenoid derivatives, compounds 1-5 and a range of their glycoside derivatives which were isolated from a complex mixture after acetylation, followed by separation (6Ac-14Ac). The structures of the unacetylated forms of these compounds, as they occur in the plant, are given in Fig. 1 and structures of all compounds isolated are provided in the ESI, S.1. $\dagger$

The HREIMS of compound $\mathbf{1}$ showed a $[\mathrm{M}+\mathrm{Na}]^{+}$peak at $\mathrm{m} / \mathrm{z}$ 407.2570 indicating a molecular formula of $\mathrm{C}_{25} \mathrm{H}_{36} \mathrm{O}_{3}$ and the presence of a pentanortriterpenoid. The IR spectrum showed peaks for lactone and keto group carbonyl stretches respectively at 1767 and $1708 \mathrm{~cm}^{-1}$. The ${ }^{1} \mathrm{H},{ }^{13} \mathrm{C},{ }^{1} \mathrm{H}-{ }^{1} \mathrm{H}$ COSY, ${ }^{1} \mathrm{H}-{ }^{13} \mathrm{C}$ HSQC, and ${ }^{1} \mathrm{H}_{-}{ }^{13} \mathrm{C}$ HMBC spectral data were used as input for 


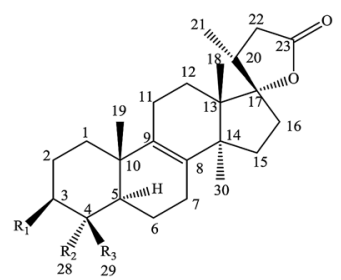

Compound 1: $\mathrm{R}_{1}==\mathrm{O}, \mathrm{R}_{2}=\mathrm{CH}_{3}, \mathrm{R}_{3}=\mathrm{H}$ Compound 2: $\mathrm{R}_{1}=\mathrm{OH}, \mathrm{R}_{2}=\mathrm{R}_{3}=\mathrm{CH}_{2} \mathrm{OH}$ Compound 2Ac: $\mathrm{R}_{1}=\mathrm{OH}, \mathrm{R}_{2}=\mathrm{R}_{3}=\mathrm{CH}_{2} \mathrm{OAc}$

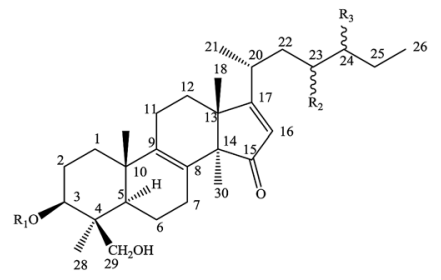

Compound 4: $\mathrm{R}_{1}=\mathrm{H}, \mathrm{R}_{2}=\mathrm{R}_{3}=\mathrm{OH}$

Compound 5: $\mathrm{R}_{1}=\mathrm{H}, \mathrm{R}_{2}=\mathrm{OH}, \mathrm{R}_{3}==\mathrm{O}$

Compound 6: $R_{1}=\beta$-D-glucopyranoside, $R_{2}=O H, R_{3}==0$

Compound 7: $\mathrm{R}_{1}=\alpha$-L-arabinopyranosyl- $(1 \rightarrow 6)-\beta$ - D-glucopyranoside $, \mathrm{R}_{2}=\mathrm{OH}, \mathrm{R}_{3}==\mathrm{O}$
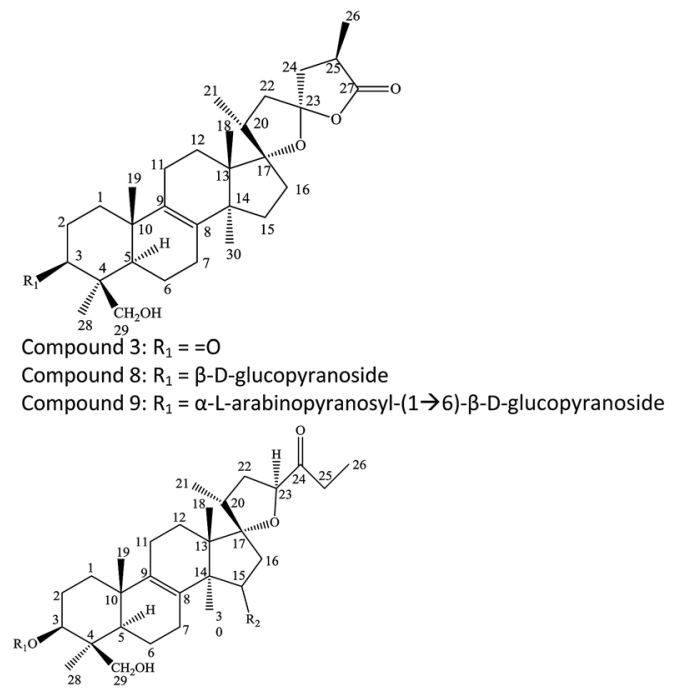

Compound 10: $R_{1}=\beta$-D-glucopyranoside, $R_{2}=H$

Compound 11: $R_{1}=\alpha$-L-arabinopyranosyl- $(1 \rightarrow 6)-\beta$ - D-glucopyranoside, $R_{2}=H$ Compound 12: $R_{1}=\beta$-D-glucopyranoside, $R_{2}==0$

Compound 13: $R_{1}=\alpha$-L-arabinopyranosyl- $(1 \rightarrow 6)-\beta$-D-glucopyranoside,$R_{2}==0$

Compound 14: $R_{1}=\beta$-D-xylopyranosyl- $(1 \rightarrow 3)-[\alpha$-L-arabinopyranoside- $(1 \rightarrow 6)]-\beta-D-$ glucopyranoside, $R_{2}==0$

Fig. 1 Compounds isolated from Eucomis bicolor.

the automatic structure elucidation software LSD. ${ }^{21,22}$ The corresponding data file is available as ESI (S.3†). The carbon atoms were numbered in the decreasing order of their ${ }^{13} \mathrm{C}$ NMR chemical shift and the hydrogen atoms were numbered so that a carbon and a hydrogen atom that are bound together have their corresponding resonances bearing the same number, according to the HSQC spectrum. The oxygen atom of the keto group was numbered 26, those from the lactone group were given the numbers $27\left(\mathrm{sp}^{2}\right)$ and $28\left(\mathrm{sp}^{3}\right)$. The assignment of the number of attached hydrogen atoms attached to each carbon atom by means of the $J$-modulated HSQC spectrum led to an overall number of carbonated hydrogens of 36, thus leaving no possibility for the presence of a hydroxy group. Carbons resonances at $213.1,177.1,135.8$, and 133.1 we produced by $\mathrm{sp}^{2}$ hybridized carbon atoms, while the one at 98.4 must be $\mathrm{sp}^{3}$ and bound to O-28. The HSQC and HMBC spectra were recorded with a resolution in the ${ }^{13} \mathrm{C}$ domain that was sufficient to avoid any ambiguity on peak positions in this domain. However, peak overlapping in the ${ }^{1} \mathrm{H}$ domain led to the existence of several HMBC correlations for which the interpretation was ambiguous and considered as such by the LSD algorithm. The COSY spectrum identified the two methyl-methine bonds of the molecule and four other carbon-carbon bonds.

The carbons of the singlet methyl groups were also forced to be bonded to quaternary carbons. These constraints and the correlation data produced a single planar structure solution when processed by the LSD software. The NOESY spectrum showed correlations between the $3 \mathrm{H}-18$ and $3 \mathrm{H}-19, \mathrm{H}-20$ and $3 \mathrm{H}-21$ resonances, between the $3 \mathrm{H}-19 / \mathrm{H}-4$ resonances and between the $3 \mathrm{H}-28 / \mathrm{H}-5$ and $3 \mathrm{H}-30 / \mathrm{H}-5$ resonances and between the $3 \mathrm{H}-21 / \mathrm{H}-12 \alpha$ resonance. Confirming that the C-21 methyl group was in the alpha orientation. Thus compound 1 was identified as (17S)-24,25,26,27,29-pentanor-3-oxo-lanost-8-en23,17 $\alpha$-olide. This compound would arise from a Michael-type addition of the oxygen of a C-23 hydroxy group oxygen to C-17 of a ring $\mathrm{D} \alpha, \beta$-unsaturated system (as seen in 4) followed by the oxidative cleavage of the lanostane C-23/C-24 bond, to yield the pentanortriterpenoid structure.

Compound 2 was isolated in very small amounts, but in larger amounts as its tri-acetyl derivative, 2Ac, after acetylation of a complex mixture. The acetate was identified as $(17 S)$ 24,25,26,27-tetranor-3 $\beta, 28,29$-triacetoxy-lanost-8-en-23,17 $\alpha$-olide, 2Ac, hence compound 2 was the novel $(17 S)-24,25,26,27$-tetranor-3 $\beta, 28,29$-trihydroxy-lanost-8-en-23,17 $\alpha$-olide. The HREIMS of compound 2Ac, showed a $[\mathrm{M}+\mathrm{Na}]^{+}$peak at $\mathrm{m} / z 581.3096$ for $\mathrm{C}_{32} \mathrm{H}_{46} \mathrm{O}_{8} \mathrm{Na}$, which indicated a molecular formula of $\mathrm{C}_{26} \mathrm{H}_{40} \mathrm{O}_{5}$ for 2 .

Compound 2Ac differed from 1 in the structure of ring A. The ${ }^{1} \mathrm{H}$ NMR spectrum of 2Ac showed that the 3-keto group had been replaced by an acetoxy group with the $\mathrm{H}-3 \alpha$ resonance occurring at $\delta 4.89(\mathrm{dd}, J=11.60,4.10)$. The corresponding C-3 resonance $(\delta 74.0)$ showed correlations in the HMBC spectrum with two sets of oxymethylene proton resonances $(2 \mathrm{H}-28, \delta 4.04$, 4.27 ea $\mathrm{d}, J=12.00 ; 2 \mathrm{H}-29, \delta 4.31,4.40$ ea $\mathrm{d}, J=12.20)$. The ${ }^{13} \mathrm{C}$ NMR spectrum displayed three acetyl carbonyl carbon resonances at $\delta_{\mathrm{C}} 170.4, \delta_{\mathrm{C}} 170.9$ and $\delta_{\mathrm{C}} 171.2$ and HMBC correlations enabled confirmation that acetylation had taken place at C-3, C-28 and C-29.

The NOESY spectrum showed similar correlations as in 1, and showed additional correlations between the $\mathrm{H}-5 / \mathrm{H}-3 \alpha / 2 \mathrm{H}-$ 28 resonances, confirming the configuration of the substituent at $\mathrm{C}-3$ as $\beta$.

The HREIMS of 3 showed a $[\mathrm{M}+\mathrm{Na}]^{+}$ion at $m / z 507.3078$ corresponding to the molecular formula $\mathrm{C}_{30} \mathrm{H}_{44} \mathrm{O}_{5}$ for the 
compound. The FTIR spectrum showed absorption bands at 1772 and $1701 \mathrm{~cm}^{-1}$ consistent with a $\gamma$-lactone and keto group respectively. ${ }^{23}$ The keto group occurred at C-3 $\left(\delta_{\mathrm{C}} 221.0\right)$ and the HMBC spectrum showed correlations between both the C-3 and C-5 $\left(\delta_{\mathrm{C}} 52.1\right)$ resonances and two $\mathrm{H}-29$ oxymethylene $\left(\delta_{\mathrm{H}} 3.24, \mathrm{~d}\right.$, $\left.J=11.20 \mathrm{~Hz} ; \delta_{\mathrm{H}} 4.02, \mathrm{~d}, J=11.20 \mathrm{~Hz}\right)$, and the $3 \mathrm{H}-28\left(\delta_{\mathrm{H}} 1.28\right)$ proton resonances. The eight carbon sidechain was modified into a spiro- $\gamma$-lactone as in compounds previously reported from Chionodoxa luciliae Boiss. ${ }^{23}$ The $\mathrm{C}-17$ resonance $\left(\delta_{\mathrm{C}} 98.7\right)$ was seen to correlated with the $3 \mathrm{H}-18\left(\delta_{\mathrm{H}}, \mathrm{H}-20\left(\delta_{\mathrm{H}} 2.28\right), 3 \mathrm{H}-21\right.$ $\left(\mathrm{d}, \delta_{\mathrm{H}} 1.05\right)$ and two $\mathrm{H}-22\left(\delta_{\mathrm{H}} 1.78\right.$ and $\left.\delta_{\mathrm{H}} 2.72\right)$ resonances in the
HMBC spectrum, and the C-23 $\left(\delta_{\mathrm{C}}\right.$ 113.4) resonance showed correlations seen with the H-20, two $\mathrm{H}-22$, two $\mathrm{H}-24\left(\delta_{\mathrm{H}} 2.00, \delta_{\mathrm{H}}\right.$ $2.47)$ and $\mathrm{H}-25\left(\delta_{\mathrm{H}} 2.97\right)$ resonances. The $\mathrm{C}-27$ lactone carbonyl resonance $\left(\delta_{\mathrm{C}} 179.0\right)$ showed correlations with the two $\mathrm{H}-24, \mathrm{H}-$ 25 and $3 \mathrm{H}-26\left(\delta_{\mathrm{H}} 1.26, \mathrm{~d}, J=7.40 \mathrm{~Hz}\right)$ resonances. The molecular formula indicated two rings in the sidechain due to the C17,23 ether and 27,23-lactone. The NOESY spectrum showed correlations between the $3 \mathrm{H}-19 / 3 \mathrm{H}-18$ and $3 \mathrm{H}-19 / \mathrm{H}-29\left(\delta_{\mathrm{H}} 4.02\right)$ resonances and $\mathrm{H}-5 / 3 \mathrm{H}-28$ resonances as expected. Correlations seen between the $3 \mathrm{H}-18 / \mathrm{H}-16 \beta / \mathrm{H}-20$ resonances confirmed the configuration at $\mathrm{C}-17$ as $S$ and that $\mathrm{H}-20$ was $\beta$. Correlations

Table $1{ }^{1} \mathrm{H}$ NMR $(500 \mathrm{MHz})$ chemical shifts for compounds $1,2,2 \mathrm{Ac}, 3,4,5\left(\mathrm{CDCl}_{3}\right)$

\begin{tabular}{|c|c|c|c|c|c|c|}
\hline No & 1 & 2 & $2 A c$ & 3 & 4 & 5 \\
\hline $1 \alpha$ & 1.57 & 1.21 & 1.38 & 1.98 & 1.22 & 1.20 \\
\hline $1 \beta$ & 2.07 & 1.74 & 1.82 & 1.76 & 1.75 & 1.76 \\
\hline $2 \alpha$ & 2.34 & 1.78 & 1.73 & 2.46 & 1.78 & 1.75 \\
\hline $2 \beta$ & 2.44 & 1.66 & 1.83 & 2.58 & 1.82 & 1.81 \\
\hline 3 & - & $3.76^{a}$ & $\begin{array}{l}4.89, \mathrm{dd} \\
J=11.60,4.10\end{array}$ & - & $\begin{array}{l}3.47, \mathrm{dd}, \\
J=9.90,4.10\end{array}$ & $\begin{array}{l}3.44, \mathrm{dd} \\
J=12.00,4.60\end{array}$ \\
\hline 4 & 2.28 & - & - & - & - & - \\
\hline 5 & 1.40 & 1.22 & 1.64 & 1.86 & $1.18, \mathrm{~m}$ & $1.18, \mathrm{~m}$ \\
\hline $6 \alpha$ & 1.46 & 1.48 & 1.63 & 1.50 & 1.38 & 1.36 \\
\hline $6 \beta$ & 1.78 & 1.77 & 1.75 & 1.69 & 1.82 & 1.83 \\
\hline $7 \alpha$ & 2.04 & 1.98 & 2.03 & 2.05 & 2.48 & 2.47 \\
\hline $7 \beta$ & 2.11 & 1.98 & & 2.05 & 2.56 & 2.26 \\
\hline $11 \alpha$ & 2.13 & 1.99 & 2.17 & 2.07 & 2.13 & 2.13 \\
\hline $11 \beta$ & 2.21 & 1.99 & & 2.07 & 2.13 & 2.13 \\
\hline $12 \alpha$ & 1.54 & 1.49 & 1.52 & 2.20 & 1.70 & 1.72 \\
\hline $12 \beta$ & 2.25 & 2.20 & 2.26 & 2.20 & 2.10 & 2.11 \\
\hline $15 \alpha$ & 1.45 & 1.42 & 1.45 & 1.38 & - & - \\
\hline $15 \beta$ & 1.75 & 1.72 & 1.76 & 1.68 & - & - \\
\hline $16 \alpha$ & 2.12 & 2.07 & 2.14 & 1.84 & $5.48 \mathrm{~s}$ & $5.61, \mathrm{~s}$ \\
\hline $16 \beta$ & $\begin{array}{l}2.72, \mathrm{~d} \\
J=6.40\end{array}$ & $\begin{array}{l}2.76, \mathrm{~d} \\
J=6.40\end{array}$ & 2.73 & 2.50 & - & - \\
\hline 18 & $1.00,3 \mathrm{H}, \mathrm{s}$ & $0.94,3 \mathrm{H}, \mathrm{s}$ & $0.96, \mathrm{~s}$ & $0.92, \mathrm{~s}$ & $0.94, \mathrm{~s}$ & $0.94, \mathrm{~s}$ \\
\hline 19 & $1.20,3 \mathrm{H}, \mathrm{s}$ & $0.96,3 \mathrm{H}, \mathrm{s}$ & $1.06, \mathrm{~s}$ & $1.05, \mathrm{~s}$ & $0.95, \mathrm{~s}$ & $0.95, \mathrm{~s}$ \\
\hline 20 & 2.49 & 2.47 & 2.50 & 2.28 & 2.80 & 2.87 \\
\hline 21 & $\begin{array}{l}1.13,3 \mathrm{H}, \mathrm{d}, \\
J=6.80\end{array}$ & $\begin{array}{l}1.10, \mathrm{~d}, \\
J=6.60\end{array}$ & $\begin{array}{l}1.14, \mathrm{~d} \\
J=6.60\end{array}$ & $1.05, \mathrm{~d}, J=6.80$ & $1.13, \mathrm{~d}, J=6.90$ & $1.13, \mathrm{~d}, J=6.50$ \\
\hline $22 \alpha$ & $2.75, \mathrm{~d}, J=6.40$ & 2.03 & 2.04 & $\begin{array}{l}2.72, \mathrm{dd}, \\
J=6.70,13.50\end{array}$ & 1.64 & 1.49 \\
\hline $22 \beta$ & 2.03 & 2.72 & $\begin{array}{l}2.77, \mathrm{~d} \\
J=6.20\end{array}$ & 1.78 & 1.73 & 2.04 \\
\hline 23 & - & - & - & - & $3.28, \mathrm{bt}^{a}$ & $3.97, \mathrm{~d}, J=11.30$ \\
\hline $24 \alpha$ & - & - & - & 2.47 & $3.31, \mathrm{~m}^{a}$ & - \\
\hline $24 \beta$ & & - & - & 2.00 & - & - \\
\hline $25 \alpha$ & - & - & - & 2.97 & $1.43^{a}$ & $2.44^{a}$ \\
\hline $25 \beta$ & - & - & - & - & $1.59^{a}$ & $2.53^{a}$ \\
\hline 26 & - & - & - & $1.26, \mathrm{~d}, J=7.40$ & $0.99, \mathrm{t}, J=7.80$ & $1.11, \mathrm{t}, J=7.40$ \\
\hline $28 \mathrm{~A}$ & $\begin{array}{l}1.02,3 \mathrm{H}, \mathrm{d}, \\
J=6.7\end{array}$ & $3.74^{a}$ & $\begin{array}{l}4.04, \mathrm{~d} \\
J=12.00\end{array}$ & 1.26 & $1.26, \mathrm{~s}$ & $1.26, \mathrm{~s}$ \\
\hline $28 \mathrm{~B}$ & - & $\begin{array}{l}4.37, \mathrm{~d} \\
J=11.60\end{array}$ & $\begin{array}{l}4.27, \mathrm{~d} \\
J=12.00\end{array}$ & - & - & - \\
\hline $29 \mathrm{~A}$ & - & $3.81^{a}$ & $\begin{array}{l}4.31, \mathrm{~d} \\
J=12.20\end{array}$ & $3.45, \mathrm{~d}, J=11.20$ & $3.38, \mathrm{~d}, J=10.90$ & $3.35, \mathrm{~d}, J=10.60$ \\
\hline 29B & - & $\begin{array}{l}4.14, \mathrm{~d}, \\
J=11.60\end{array}$ & $4.40, \mathrm{~d}, J=12.20$ & $4.02, \mathrm{~d}, J=11.20$ & $4.23, \mathrm{~d}, J=10.90$ & $4.23, \mathrm{~d}, J=10.60$ \\
\hline 30 & $1.10,3 \mathrm{H}, \mathrm{s}$ & $1.09, \mathrm{~s}$ & $1.11, \mathrm{~s}$ & $1.05, \mathrm{~s}$ & $1.20, \mathrm{~s}$ & $1.21, \mathrm{~s}$ \\
\hline $\mathrm{COCH}_{3}$ & - & - & $2.2,2.06 \mathrm{~s}, 2.08 \mathrm{~s}$ & - & - & - \\
\hline
\end{tabular}

${ }^{a}$ Superimposed resonances, $J$ not clear. 
seen between the $3 \mathrm{H}-26$ and two $\mathrm{H}-22$ resonances confirmed the configuration at C-23 as $S$. Compound 3 was identified as (17S,23S)-17a,23-epoxy-29-hydroxylanosta-8-en-3-on-27,23olide.

The HREIMS of compound 4 showed a $[\mathrm{M}+\mathrm{Na}]^{+}$peak at $\mathrm{m} / \mathrm{z}$ 497.3225 which corresponded to a molecular formula of $\mathrm{C}_{29} \mathrm{H}_{46} \mathrm{O}_{5}$ for the compound. The oxymethine C-3 resonance $\left(\delta_{\mathrm{C}}\right.$ 80.8), showed correlations in the HMBC spectrum with the H-5 $(J=10.9 \mathrm{~Hz} 1.18)$, the $3 \mathrm{H}-28\left(\delta_{\mathrm{H}} 1.26\right)$ and the two $\mathrm{H}-29\left(\delta_{\mathrm{H}} 3.35\right.$, d, $\delta_{\mathrm{H}} 4.23$, d, both $\left.J=10.9 \mathrm{~Hz}\right)$ resonances, indicating the presence of an oxymethylene group at C-29 as in 3. Correlations seen in the NOESY spectrum between the $\mathrm{H}-3\left(\delta_{\mathrm{H}} 3.47, \mathrm{dd}, J=\right.$ 9.90, $4.10 \mathrm{~Hz}$ ), $3 \mathrm{H}-28$ and $\mathrm{H}-5$ resonances, confirmed that $\mathrm{H}-3$ was $\alpha$, and a correlation was noted between the two $\mathrm{H}-29$ and $3 \mathrm{H}-19$ resonance $\left(\delta_{\mathrm{H}} 0.95\right)$. The structure of ring $\mathrm{D}$ differed from that of the previous compounds having an $\alpha, \beta$-unsaturated ring ketone, showed by resonances at $\delta_{\mathrm{C}} 186.6$ (C-17), $\delta_{\mathrm{C}} 123.0$ (C-16) and $\delta_{\mathrm{C}} 210.1(\mathrm{C}-15) .{ }^{24}$ The $\mathrm{C}-17$ resonance showed correlations in the HMBC spectrum with the H-16 $\left(\delta_{\mathrm{H}} 5.61\right), 3 \mathrm{H}-18\left(\delta_{\mathrm{H}} 0.94\right)$, $\mathrm{H}-20\left(\delta_{\mathrm{H}} 2.80\right), 3 \mathrm{H}-21\left(\delta_{\mathrm{H}} 1.13, \mathrm{~d}, J=6.9 \mathrm{~Hz}\right)$, and two $\mathrm{H}-22\left(\delta_{\mathrm{H}}\right.$ 1.64 and $\left.\delta_{\mathrm{H}} 1.73\right)$ resonances, and the $\mathrm{C}-15$ resonance showed correlations with the $3 \mathrm{H}-30\left(\delta_{\mathrm{H}} 1.20\right)$ and $\mathrm{H}-16$ resonances. The COSY spectrum showed coupling between the two H-22, and the oxymethine $\mathrm{H}-23$ resonance $\left(\delta_{\mathrm{H}} 3.28\right)$, between $\mathrm{H}-23$ and the oxymethine $\mathrm{H}-24$ resonance $\left(\delta_{\mathrm{H}} 3.31\right)$ and between the $\mathrm{H}-24 / 2 \mathrm{H}^{-}$ $25\left(\delta_{\mathrm{H}} 1.43,1.59\right)$ and $2 \mathrm{H}-25 / 3 \mathrm{H}-26\left(\delta_{\mathrm{H}} 0.99, \mathrm{t}, J=7.80\right)$ resonances.

The configuration at C-23 of the co-isolated $\mathbf{3}$ and $\mathbf{1 0}$ have been determined unequivocally as $S$, so it was assumed that if compounds like $\mathbf{4}$ are their precursors, the configuration at C-23 should be the same $(S)$. An attempt was made to determine the configuration at $\mathrm{C}-24$ of the side chain vic-diol employing acyclic 1,2-diol complexation with $\left[\mathrm{Mo}_{2}(\mathrm{OAc})_{4}\right]$ and subsequent CD measurements. ${ }^{25}$ However, results were inconclusive. Thus 4 was identified as $3 \beta, 23 S, 24 \varepsilon, 29$-tetrahydroxy-27-norlanosta-816-diene-15-one.

The HREIMS of compound 5 showed $[\mathrm{M}+\mathrm{Na}]^{+}$at $\mathrm{m} / \mathrm{z}$ 495.3071 which corresponded to the molecular formula $\mathrm{C}_{29} \mathrm{H}_{44} \mathrm{O}_{5}$ for the compound. The $\mathrm{C}-24$ hydroxyl group in compound 4 was oxidised to a keto group $\left(\delta_{\mathrm{C}} 212.6\right)$ in

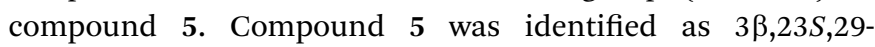
trihydroxy-27-norlanosta-8-16-diene-15,24-dione, which has been prepared previously as a derivative of eucosterol but incomplete ${ }^{1} \mathrm{H}$ NMR and ${ }^{13}{ }^{13} \mathrm{NMR}$ data was provided. ${ }^{24}$

The HRMS of compound 6Ac gave an $[\mathrm{M}+\mathrm{Na}]^{+}$ion at $\mathrm{m} / \mathrm{z}$ 909.4254 indicating the molecular formula of $\mathrm{C}_{47} \mathrm{H}_{66} \mathrm{O}_{16}$ for this compound. The FTIR spectrum for this compound showed a broad absorption at $1749 \mathrm{~cm}^{-1}$ for the carbonyl groups, 2937 $\mathrm{cm}^{-1}$ and $2868 \mathrm{~cm}^{-1}$ for the aliphatic $\mathrm{CH}$ stretches and 1222 $\mathrm{cm}^{-1}$ for a C-O stretch. The ${ }^{13} \mathrm{C}$ NMR spectrum indicated that compound $6 \mathrm{Ac}$ was the acetylated form of the C-3 $\beta, \beta$-D-glucoside derivative of compound 5 . The ${ }^{1} \mathrm{H}$ NMR spectrum showed acetylation had occurred at the C-29 and the C-23 hydroxy groups by downfield shifts of the $\mathrm{H}-23$ and two $\mathrm{H}-29$ proton resonances compared to those of $\mathbf{5}$ (Tables 1 and 3$)$. The C-3 $\left(\delta_{\mathrm{C}}\right.$ 90.1) resonance showed a correlation in the HMBC spectrum with an anomeric proton resonance at $\delta_{\mathrm{H}} 4.54$ and the COSY
Table $2{ }^{13} \mathrm{C}$ NMR (125 MHz) chemical shifts for compounds 1, 2, 2Ac, $3,4,5\left(\mathrm{CDCl}_{3}\right)$

\begin{tabular}{|c|c|c|c|c|c|c|}
\hline No & 1 & 2 & $2 a$ & 3 & 4 & 5 \\
\hline 1 & $37.1 \mathrm{CH}_{2}$ & $35.3 \mathrm{CH}_{2}$ & $35.3 \mathrm{CH}_{2}$ & $35.6 \mathrm{CH}_{2}$ & $35.2 \mathrm{CH}_{2}$ & $35.2 \mathrm{CH}_{2}$ \\
\hline 2 & $38.0 \mathrm{CH}_{2}$ & $27.6 \mathrm{CH}_{2}$ & $23.9 \mathrm{CH}_{2}$ & $29.0 \mathrm{CH}_{2}$ & $28.2 \mathrm{CH}_{2}$ & $28.2 \mathrm{CH}_{2}$ \\
\hline 3 & $213.1 \mathrm{C}$ & $77.9 \mathrm{CH}$ & $74.0 \mathrm{CH}$ & $221.0 \mathrm{C}$ & $80.9 \mathrm{CH}$ & $80.8 \mathrm{CH}$ \\
\hline 4 & $45.2 \mathrm{CH}$ & $46.1 \mathrm{C}$ & $44.1 \mathrm{C}$ & $51.3 \mathrm{C}$ & $43.0 \mathrm{C}$ & $42.9 \mathrm{C}$ \\
\hline 5 & $49.7 \mathrm{CH}$ & $47.5 \mathrm{CH}$ & $44.5 \mathrm{CH}$ & $52.1 \mathrm{CH}$ & $51.2 \mathrm{CH}$ & $51.2 \mathrm{CH}$ \\
\hline 6 & $22.1 \mathrm{CH}_{2}$ & $18.8 \mathrm{CH}_{2}$ & $19.4 \mathrm{CH}_{2}$ & $19.1 \mathrm{CH}_{2}$ & $18.4 \mathrm{CH}_{2}$ & $18.1 \mathrm{CH}_{2}$ \\
\hline 7 & $25.4 \mathrm{CH}_{2}$ & $26.3 \mathrm{CH}_{2}$ & $26.8 \mathrm{CH}_{2}$ & $26.2 \mathrm{CH}_{2}$ & $27.4 \mathrm{CH}_{2}$ & $27.7 \mathrm{CH}_{2}$ \\
\hline 8 & $135.8 \mathrm{C}$ & $134.8 \mathrm{C}$ & $135.2 \mathrm{C}$ & $132.6 \mathrm{C}$ & 133.6 C & $133.4 \mathrm{C}$ \\
\hline 9 & $133.1 \mathrm{C}$ & $134.6 \mathrm{C}$ & $134.5 \mathrm{C}$ & $136.3 \mathrm{C}$ & $135.8 \mathrm{C}$ & 136.1 C \\
\hline 10 & $36.8 \mathrm{C}$ & $36.9 \mathrm{C}$ & $37.1 \mathrm{C}$ & $37.0 \mathrm{C}$ & $37.5 \mathrm{C}$ & $37.6 \mathrm{C}$ \\
\hline 11 & $21.5 \mathrm{CH}_{2}$ & $20.8 \mathrm{CH}_{2}$ & $20.7 \mathrm{CH}_{2}$ & $21.0 \mathrm{CH}_{2}$ & $20.6 \mathrm{CH}_{2}$ & $20.4 \mathrm{CH}_{2}$ \\
\hline 12 & $24.7 \mathrm{CH}_{2}$ & $24.6 \mathrm{CH}_{2}$ & $24.6 \mathrm{CH}_{2}$ & $25.0 \mathrm{CH}_{2}$ & $23.3 \mathrm{CH}_{2}$ & $23.2 \mathrm{CH}_{2}$ \\
\hline 13 & $50.9 \mathrm{C}$ & $50.8 \mathrm{C}$ & $50.9 \mathrm{C}$ & $48.7 \mathrm{C}$ & $51.2 \mathrm{C}$ & $51.2 \mathrm{C}$ \\
\hline 14 & $49.0 \mathrm{C}$ & $49.0 \mathrm{C}$ & $49.0 \mathrm{C}$ & $50.7 \mathrm{C}$ & $57.3 \mathrm{C}$ & $57.3 \mathrm{C}$ \\
\hline 15 & $31.5 \mathrm{CH}_{2}$ & $31.5 \mathrm{CH}_{2}$ & $31.5 \mathrm{CH}_{2}$ & $31.9 \mathrm{CH}_{2}$ & $210.2 \mathrm{C}$ & $210.1 \mathrm{C}$ \\
\hline 16 & $39.3 \mathrm{CH}_{2}$ & $39.4 \mathrm{CH}_{2}$ & $39.3 \mathrm{CH}_{2}$ & $37.3 \mathrm{CH}_{2}$ & $123.0 \mathrm{CH}$ & $123.0 \mathrm{CH}$ \\
\hline 17 & $98.4 \mathrm{C}$ & 98.6 C & $98.4 \mathrm{C}$ & 98.7 C & $186.6 \mathrm{C}$ & $185.8 \mathrm{C}$ \\
\hline 18 & $18.2 \mathrm{CH}_{3}$ & $17.9 \mathrm{CH}_{3}$ & $18.3 \mathrm{CH}_{3}$ & $18.9 \mathrm{CH}_{3}$ & $28.8 \mathrm{CH}_{3}$ & $28.8 \mathrm{CH}_{3}$ \\
\hline 19 & $17.7 \mathrm{CH}_{3}$ & $19.8 \mathrm{CH}_{3}$ & $19.3 \mathrm{CH}_{3}$ & $19.9 \mathrm{CH}_{3}$ & $19.7 \mathrm{CH}_{3}$ & $19.8 \mathrm{CH}_{3}$ \\
\hline 20 & $41.9 \mathrm{CH}$ & $41.9 \mathrm{CH}$ & $41.9 \mathrm{CH}$ & $44.0 \mathrm{CH}$ & $30.1 \mathrm{CH}$ & $30.2 \mathrm{CH}$ \\
\hline 21 & $17.9 \mathrm{CH}_{3}$ & $17.9 \mathrm{CH}_{3}$ & $17.9 \mathrm{CH}_{3}$ & $18.8 \mathrm{CH}_{3}$ & $21.7 \mathrm{CH}_{3}$ & $21.7 \mathrm{CH}_{3}$ \\
\hline 22 & $39.2 \mathrm{CH}_{2}$ & $39.2 \mathrm{CH}_{2}$ & $39.2 \mathrm{CH}_{2}$ & $32.0 \mathrm{CH}_{2}$ & $39.4 \mathrm{CH}_{2}$ & $39.6 \mathrm{CH}_{2}$ \\
\hline 23 & $177.1 \mathrm{C}$ & $177.4 \mathrm{C}$ & $177.4 \mathrm{C}$ & $113.4 \mathrm{C}$ & $71.9 \mathrm{CH}$ & $74.3 \mathrm{CH}$ \\
\hline 24 & - & - & - & $45.1 \mathrm{CH}_{2}$ & $76.9 \mathrm{CH}$ & $212.6 \mathrm{C}$ \\
\hline 25 & - & - & - & $35.8 \mathrm{CH}$ & $26.7 \mathrm{CH}_{2}$ & $31.4 \mathrm{CH}_{2}$ \\
\hline 26 & - & - & - & $15.1 \mathrm{CH}_{3}$ & $10.2 \mathrm{CH}_{3}$ & $7.8 \mathrm{CH}_{3}$ \\
\hline 27 & - & - & - & $179.0 \mathrm{C}$ & - & - \\
\hline 28 & $11.7 \mathrm{CH}_{3}$ & $63.9 \mathrm{CH}_{2}$ & $62.7 \mathrm{CH}_{2}$ & $22.1 \mathrm{CH}_{3}$ & $22.5 \mathrm{CH}_{3}$ & $22.5 \mathrm{CH}_{3}$ \\
\hline 29 & - & $71.4 \mathrm{CH}_{2}$ & $63.8 \mathrm{CH}_{2}$ & $66.1 \mathrm{CH}_{2}$ & $64.5 \mathrm{CH}_{2}$ & $64.5 \mathrm{CH}_{2}$ \\
\hline 30 & $25.9 \mathrm{CH}_{3}$ & $25.8 \mathrm{CH}_{3}$ & $25.7 \mathrm{CH}_{3}$ & $26.2 \mathrm{CH}_{3}$ & $29.6 \mathrm{CH}_{3}$ & $29.6 \mathrm{CH}_{3}$ \\
\hline 1-OAc & - & - & $21.4 \mathrm{CH}_{3}$ & - & - & - \\
\hline 2-OAc & - & - & $21.3 \mathrm{CH}_{3}$ & - & - & - \\
\hline 3-OAc & - & - & $21.2 \mathrm{CH}_{3}$ & - & - & - \\
\hline 1-OAc & - & - & $170.4 \mathrm{C}$ & - & - & - \\
\hline 2-OAc & - & - & $170.9 \mathrm{C}$ & - & - & - \\
\hline 3-OAc & - & - & $171.2 \mathrm{C}$ & - & - & - \\
\hline
\end{tabular}

and HSQC spectra enabled assignment of the sugar resonances. The correlations seen in the NOESY spectrum between $\mathrm{H}-1^{\prime} / \mathrm{H}-3^{\prime}$ and $\mathrm{H}-2^{\prime} / \mathrm{H}-4^{\prime}$ resonances, and the coupling constants $J_{1^{\prime}, 2^{\prime}}(8.0$ $\mathrm{Hz})$ and $J_{3^{\prime}, 4^{\prime}}(9.6 \mathrm{~Hz})$ confirmed that the sugar present was acetylated $\beta$-D-glucose. ${ }^{26}$ Thus, compound 6Ac is $23 S, 29$-diacetoxy-3 $\beta-\left[2^{\prime}, 3^{\prime}, 4^{\prime}, 6^{\prime}\right.$-tetra- $O$-acetyl-O- $\beta$-D-glucopyranoside]-27norlanosta-8,16-diene-15,24-dione.

Compound 7Ac was identified as 23S,29-diacetoxy-3 $\beta$ $\left[2^{\prime}, 3^{\prime}, 4^{\prime}\right.$-tri- $O$-acetyl-O- $\beta$-D-glucopyranoside- $\left(1^{\prime \prime} \rightarrow 6^{\prime}\right)-2^{\prime \prime}, 3^{\prime \prime}, 4^{\prime \prime}$-tri$O$-acetyl- $\beta$-D-arabinopyranosyl]-27-norlanosta-8,16-diene-15,24dione. The HRMS spectrum for compound 7Ac gave a $[\mathrm{M}+\mathrm{Na}]^{+}$ ion at $\mathrm{m} / \mathrm{z} 1125.4865$ indicating a molecular formula of $\mathrm{C}_{56} \mathrm{H}_{78} \mathrm{O}_{22}$ for this acetylated compound. The aglycone part of compound was found to be the same as for compounds $5 \mathrm{Ac}$ and 6Ac. However, in addition to the acetylated $\beta$-D-glucose at C-3 $\beta$, the molecular formula indicated an additional acetylated pentose sugar and this was confirmed by the ${ }^{13} \mathrm{C}$ NMR spectrum which displayed two characteristic anomeric carbon resonances at $\delta_{\mathrm{C}} 102.7$ in table $\left(\mathrm{C}-1^{\prime}\right)$ and $\delta_{\mathrm{C}} 101.1$ in table $\left(\mathrm{C}-1^{\prime \prime}\right)$ with 
| 至 ل)

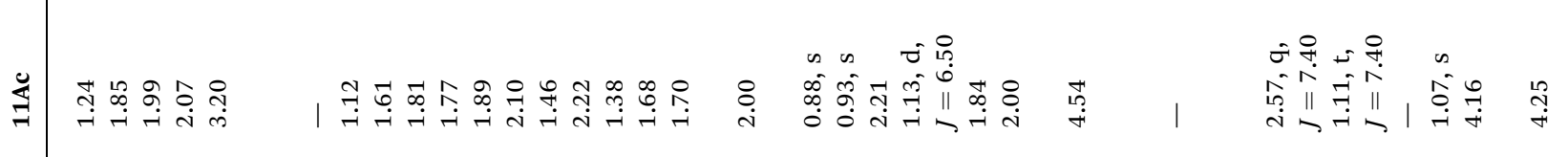

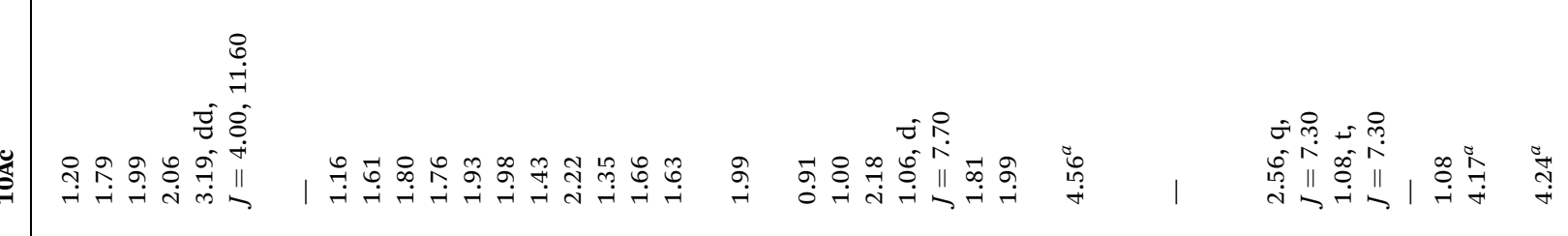

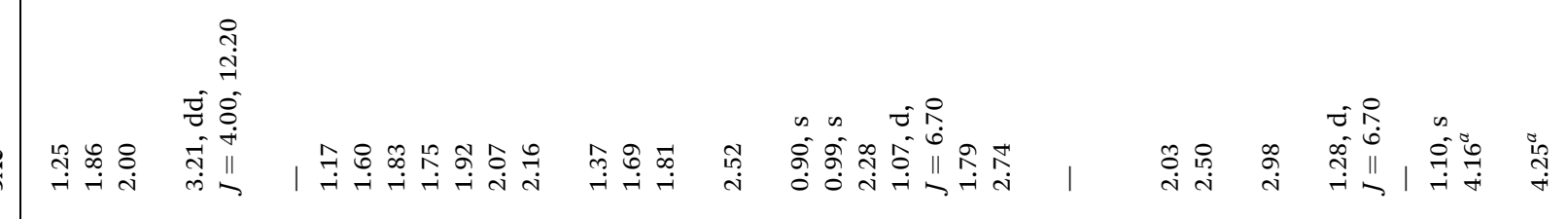

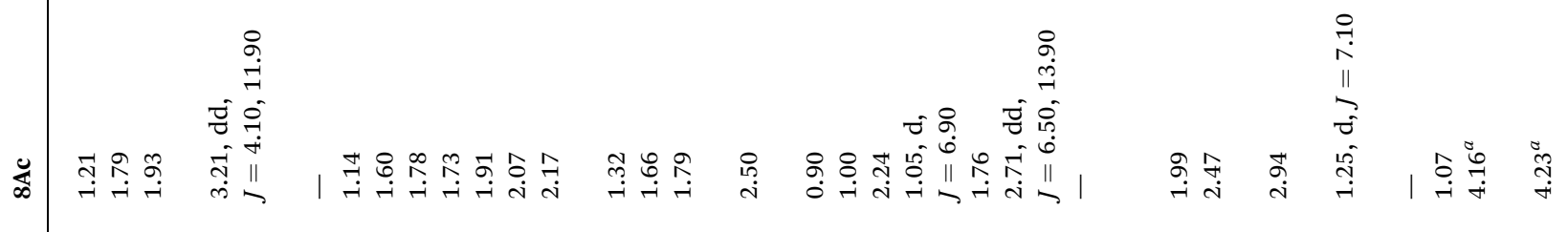

ำ

चี लें

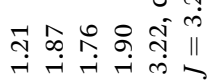

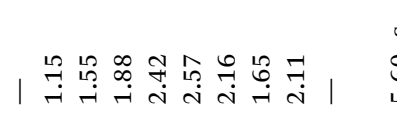
$\infty$
0
0
in

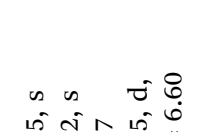

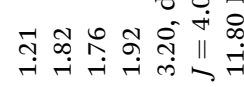

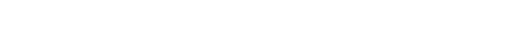

䫆 


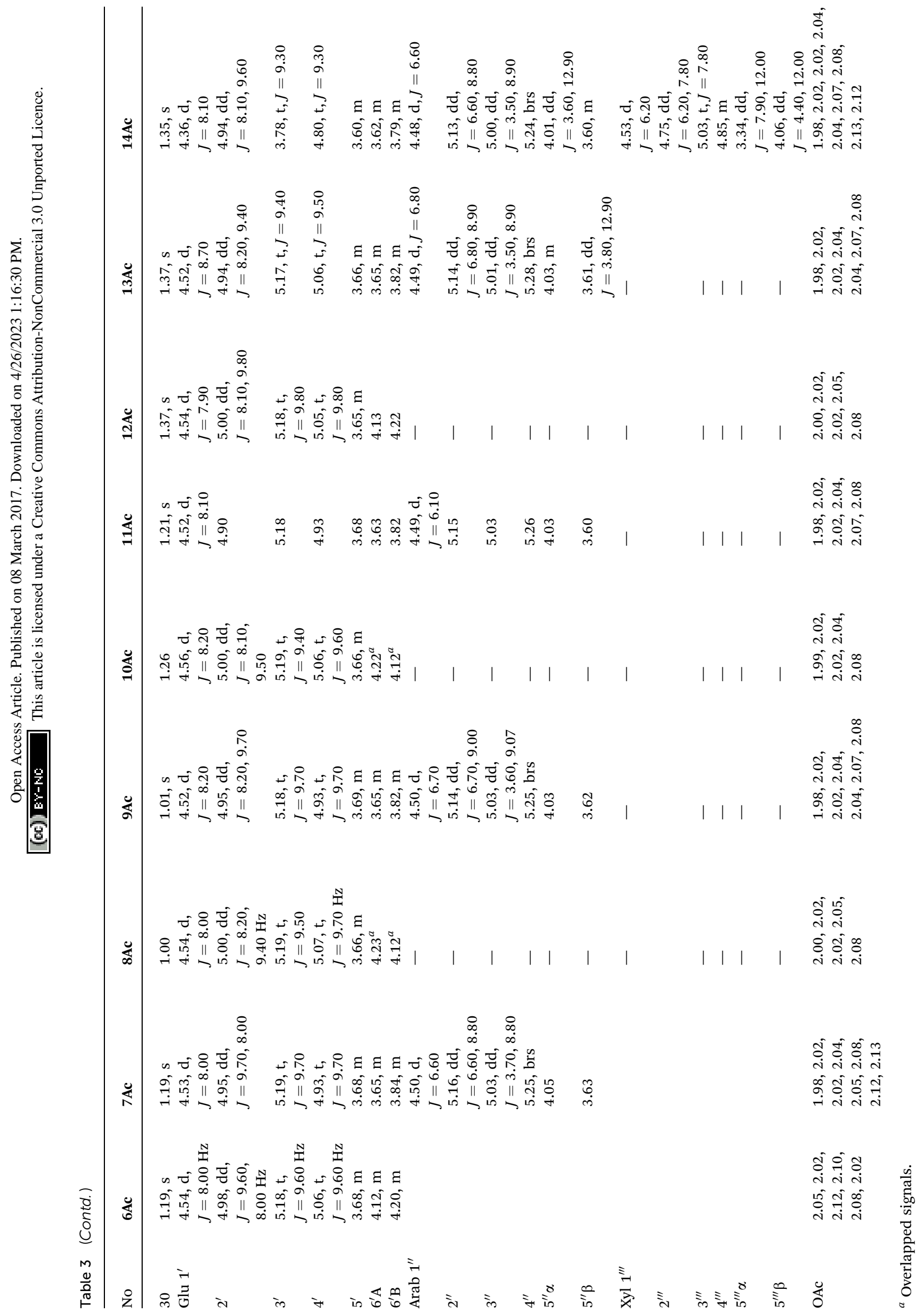


corresponding anomeric proton resonances at $\delta_{\mathrm{H}} 4.53(\mathrm{~d}, J=8.0$ $\mathrm{Hz})$ and $\delta_{\mathrm{H}} 4.50(\mathrm{~d}, J=6.6 \mathrm{~Hz})$. The anomeric proton resonance at $\delta_{\mathrm{H}} 4.50$, assigned as $\mathrm{H}-1^{\prime \prime}$, was seen to correlate in the HMBC spectrum to C- $6^{\prime}$ of $\beta$-D-glucose of C- $6^{\prime}$ indicating a $1^{\prime \prime} \rightarrow 6^{\prime}$ linkage. The COSY and HSQC spectra were again used to assign the pentose sugar resonance sand the NOESY spectrum and coupling constants were used to confirm whether the pentose was xylose or arabinose. The coupling constants of $J_{1^{\prime \prime}, 2^{\prime \prime}}=$ $6.60 \mathrm{~Hz}, J_{, 2^{\prime \prime}, 3^{\prime \prime \prime}}=8.80 \mathrm{~Hz}$ and $J_{3^{\prime \prime}, 4^{\prime \prime}}=3.70 \mathrm{~Hz}$ indicated that $\mathrm{H}-$ $1^{\prime \prime} / \mathrm{H}-2^{\prime \prime}$ and $\mathrm{H}-2^{\prime \prime \prime} / \mathrm{H}-3^{\prime \prime \prime}$ are trans-diaxial and that $\mathrm{H}-3^{\prime \prime}$ and $\mathrm{H}-4^{\prime \prime}$ have an axial-equatorial relationship. Hence, the sugar was identified as $\beta$-D-arabinose and this was supported by correlations seen in the NOESY spectrum between the $\mathrm{H}-1^{\prime \prime} / \mathrm{H}-3^{\prime \prime}, \mathrm{H}-3^{\prime \prime}$ / $\mathrm{H}-4^{\prime \prime}, \mathrm{H}-4^{\prime \prime} / \mathrm{H}_{\beta}-5^{\prime \prime}$ and $\mathrm{H}-1^{\prime \prime} / \mathrm{H}_{\alpha}-5^{\prime \prime}$ resonances.

Compound 8Ac was identified as $(17 S, 23 S)$-29-acetoxy-23,17epoxy-3 $\beta$ - $\left[2^{\prime}, 3^{\prime}, 4^{\prime}, 6^{\prime}\right.$-tetra- $O$-acetyl- $O$ - $\beta$-D-glucopyranoside]-lanost8 -en-27,23-olide, the $3 \beta$ - $\beta$-D-glucoside derivative of compound 3. The molecular ion could not be observed in the LCMS spectrum for compound 8Ac, but the structure could be determined from NMR studies. The ${ }^{13} \mathrm{C}$ NMR chemical shifts for the aglycone part were similar to those of compound 3, except that the C-3 keto group carbon was replaced by an oxymethine resonance $\left(\delta_{\mathrm{C}}\right.$ 90.4) and the C-29 hydroxy group had been acetylated. The HMBC spectrum showed a correlation between the $\mathrm{H}-3 \alpha$ proton resonances $\left(\delta_{\mathrm{H}} 3.21, \mathrm{~d}, J=4.1,11.9 \mathrm{~Hz}\right)$ and an anomeric carbon resonance $\left(\delta_{\mathrm{C}}\right.$ 103.2), which corresponded to the proton resonance at $\delta_{\mathrm{H}} 4.54(\mathrm{~d}, J=8.0 \mathrm{~Hz})$. The coupling constants and NOESY correlations of the sugar present were the same as those of compound 6Ac, indicating that the sugar present was acetylated $\beta$-D-glucose.

Compound 9Ac was identified as $(17 S, 23 S)$-29-acetoxy-23,17epoxy-3 $\beta$ - $\left[2^{\prime}, 3^{\prime}, 4^{\prime}\right.$-tri- $O$-acetyl-O- $\beta$-D-glucopyranoside- $\left(1^{\prime \prime} \rightarrow 6^{\prime}\right)$ $2^{\prime \prime}, 3^{\prime \prime}, 4^{\prime \prime}$-tri- $O$-acetyl- $O$ - $\beta$-D-arabinopyranosyl]-lanost-8-en-27,23olide. The HRMS for compound 9Ac gave a $[\mathrm{M}+\mathrm{Na}]^{+}$ion at $\mathrm{m} / \mathrm{z}$ 1097.4880, which indicated the molecular formula of $\mathrm{C}_{55} \mathrm{H}_{78} \mathrm{O}_{21}$ for this compound. The ${ }^{13} \mathrm{C}$ NMR spectrum displayed fifty-five carbon resonances, and showed that the aglycone structure was the same as for 8Ac, but that an extra $\beta$-D-arabinose sugar was present and linked as determined for 7Ac.

Compound 10Ac was identified as $(17 S, 23 S)$-29-acetoxy-23,17epoxy-3 $\beta$-[2 $2^{\prime}, 3^{\prime}, 4^{\prime}, 6^{\prime}$-tetra- $O$-acetyl- $O$ - $\beta$-D-glucopyranoside $]-27-$ norlanost-8-en-24-one. The LCMS spectrum for compound 10Ac gave a $[\mathrm{M}]^{+}$ion at $m / z 830.4421$, which indicated the molecular formula of $\mathrm{C}_{45} \mathrm{H}_{66} \mathrm{O}_{14}$ for this compound. The aglycone part of the molecule was found to be the 29-acetyl derivative of the coisolated 15-deoxyeucosterol. The C-17 $\left(\delta_{\mathrm{C}}\right.$ 97.3) resonance showed correlations in the HMBC spectrum with the $3 \mathrm{H}-19\left(\delta_{\mathrm{H}}\right.$ $1.00), \mathrm{H}-20\left(\delta_{\mathrm{H}} 1.26\right), 3 \mathrm{H}-21\left(\delta_{\mathrm{H}} 1.06, \mathrm{~d}, J=7.0 \mathrm{~Hz}\right)$, two $\mathrm{H}-22\left(\delta_{\mathrm{H}}\right.$ 1.81 and $\left.\delta_{\mathrm{H}} 1.99\right)$ and $\mathrm{H}-23\left(\delta_{\mathrm{H}} 4.56\right)$ resonances. A ketone carbon resonance at $\delta_{\mathrm{C}} 213.3$ was assigned as C-24 as it showed correlations with the two $\mathrm{H}-22, \mathrm{H}-23$, two $\mathrm{H}-25\left(\delta_{\mathrm{H}} 2.56, \mathrm{q}, J=\right.$ $7.3 \mathrm{~Hz})$ and $3 \mathrm{H}-26\left(\delta_{\mathrm{H}} 1.08, \mathrm{t}, J=7.3 \mathrm{~Hz}\right)$ resonances. The $\mathrm{H}-29$ protons occurred as a pair of doublets $\left(\delta_{\mathrm{H}} 4.17, \delta_{\mathrm{H}} 4.24\right)$ and $\mathrm{H}-3$ $\alpha$ at $\delta_{\mathrm{H}} 3.19(\mathrm{dd}, J=4.0,11.6 \mathrm{~Hz})$. The $\mathrm{C}-3$ resonance showed a correlation in the $\mathrm{HMBC}$ spectrum with the anomeric proton resonance at $\delta_{\mathrm{H}}$ 4.56. The chemical shifts, coupling constants and correlations seen in the NOESY spectrum of the sugar present were the same as those of the acetylated $\beta$-D-glucose in compounds 6Ac and 8Ac. Oxidative cleavage of the C-23/C-24 bond of 10Ac would lead to the $\gamma$-lactone structure seen in 1 and 2.

Compound 11Ac was identified as $(17 S, 23 S)$-29-acetoxy-23,17epoxy-3 $\beta$ - $\left[2^{\prime}, 3^{\prime}, 4^{\prime}\right.$-tri-O-acetyl-O- $\beta$-D-glucopyranoside- $\left(1^{\prime \prime} \rightarrow 6^{\prime}\right)$ $2^{\prime \prime}, 3^{\prime \prime}, 4^{\prime \prime}$-tri-O-acetyl-O- $\beta$-D-arabinopyranosyl]-27-norlanost-8-en-24one. The expected $[\mathrm{M}+\mathrm{Na}]^{+}$peak at $m / z 1069.4984$ for this compound was not observed in the LCMS spectrum, however, a base peak at $m / z 587.1579$, which was attributed to the acetylated disaccharide fragment $\left[\mathrm{C}_{23} \mathrm{H}_{31} \mathrm{O}_{16} \mathrm{Na}+\mathrm{H}\right]^{+}$was observed. The extra hydrogen is unusual, but was also found in compound 14Ac. It is suggested that this hydrogen comes from the triterpenoid system, solvent or electrospray buffer system. As with compounds 6Ac/7Ac and 8Ac/9Ac, compound 11Ac differed from 10Ac in having an extra acetylated $\beta$-D-arabinose group at C- $6^{\prime}$. This was confirmed using 2D NMR correlations and ${ }^{1} \mathrm{H}$ NMR coupling constants.

The HRMS spectrum for compound 12Ac, $(17 S, 23 S)$-29-acetoxy-23,17-epoxy-3 $\beta$ - $\left[2^{\prime}, 3^{\prime}, 4^{\prime} 6^{\prime}\right.$-tetra- $O$-acetyl- $O$ - $\beta$-D-glucopyranoside]-27-norlanost-8-ene-15,24-dione, gave a $[\mathrm{M}+\mathrm{Na}]^{+}$ion at $\mathrm{m} / z$ 867.4147, which indicated the molecular formula of $\mathrm{C}_{45} \mathrm{H}_{64} \mathrm{O}_{15}$ for this compound. 12Ac was the 15-keto derivative of 10Ac. The C-15 $\left(\delta_{\mathrm{C}} 215.6\right)$ resonance showed correlations in the HMBC spectrum with the $3 \mathrm{H}-30\left(\delta_{\mathrm{H}} 1.37\right)$ and pair of $\mathrm{H}-16(2.22,2.77$, ea $\mathrm{d}, J=19.2 \mathrm{~Hz}$ ) proton resonances.

Compound 13Ac was identified as the 15-keto derivative of 11Ac, $\quad(17 S, 23 S)$-29-acetoxy-23,17-epoxy-3 $\beta$ - $\left[2^{\prime}, 3^{\prime}, 4^{\prime}\right.$-tri- $O$-acetyl$O$ - $\beta$-D-glucopyranoside- $\left(1^{\prime \prime} \rightarrow 6^{\prime}\right)-2^{\prime \prime}, 3^{\prime \prime}, 4^{\prime \prime}$-tri- $O$-acetyl- $O$ - $\beta$-Darabinopyranosyl]-27-norlanost-8-ene-15,24-dione). The HRMS spectrum gave a $[\mathrm{M}+\mathrm{Na}]^{+}$ion at $m / z 1083.4739$ which corresponded to the molecular formula of $\mathrm{C}_{54} \mathrm{H}_{76} \mathrm{O}_{21}$ for this compound. The NMR spectra showed one fewer methylene group but an extra C-15 ketone carbonyl carbon resonance $\left(\delta_{\mathrm{C}}\right.$ 215.6) which showed correlations in the HMBC spectrum with the $3 \mathrm{H}-30\left(\delta_{\mathrm{H}} 1.37\right)$ and two $\mathrm{H}-16\left(\delta_{\mathrm{H}} 2.22\right.$ and 2.77 , ea $\mathrm{d}, J=19.2$ $\mathrm{Hz}$ ) resonances. The identification of the sugars was done as for the previous disaccharides isolated.

Compound 14Ac was identified as the acetylated trisaccharide of eucosterol, $(17 S, 23 S)$-29-acetoxy-23,17-epoxy-3 $\beta$ - $\left[2^{\prime}, 3^{\prime}, 4^{\prime}\right.$-tri-Oacetyl-O- $\beta$-D-glucopyranoside- $\left(1^{\prime \prime} \rightarrow 6^{\prime}\right)-2^{\prime \prime}, 3^{\prime \prime}, 4^{\prime \prime}$-tri-O-acetyl-O- $\beta$-Darabinopyranosyl-( $\left.1^{\prime \prime \prime} \rightarrow 3^{\prime}\right)-2^{\prime \prime \prime}, 3^{\prime \prime \prime}, 4^{\prime \prime \prime}$-tri- $O$-acetyl- $O-\beta$-D-xylopyranosyl]-27-norlanost-8-ene-15,24-dione. The expected $[\mathrm{M}+\mathrm{Na}]^{+}$ peak at $m / z 1276.5513$ for this compound was not observed in the LCMS spectrum. However, a base peak at $m / z$ 803.2235, which was attributed to the acetylated trisaccharide fragment $\left[\mathrm{C}_{32} \mathrm{H}_{43} \mathrm{O}_{22} \mathrm{Na}\right.$ $+\mathrm{H}]^{+}$was observed, similar to that seen in the MS of compound 11Ac. The ${ }^{13} \mathrm{C}$ NMR spectrum displayed sixty-three carbons resonance and the aglycone part was found to be the same as in compounds 12Ac and 13Ac. The ${ }^{13} \mathrm{C}$ NMR spectrum displayed three anomeric carbon resonances at $\delta_{\mathrm{C}} 100.3, \delta_{\mathrm{C}} 101.7$ and $\delta_{\mathrm{C}}$ 102.7, which corresponded to the proton resonances at $\delta_{\mathrm{H}} 4.48(\mathrm{~d}$, $J=6.6 \mathrm{~Hz}), \delta_{\mathrm{H}} 4.53(\mathrm{~d}, J=6.2 \mathrm{~Hz})$ and $\delta_{\mathrm{H}} 4.36(\mathrm{~d}, J=8.1 \mathrm{~Hz})$, respectively, confirming that compound 14Ac possessed three sugar groups. The C-3 resonance was seen to correlate in the HMBC spectrum with the resonance at $\delta_{\mathrm{H}} 4.36$, which was assigned as $\mathrm{H}^{\prime} \mathbf{1}^{\prime}$. This was used as a starting point to assign the 
chemical shifts of the first sugar. The COSY and HSQC spectrum enabled all ${ }^{1} \mathrm{H}$ and ${ }^{13} \mathrm{C}$ NMR resonances for the sugar at C-3 $\beta$ to be assigned and the large coupling constants $\left(J_{1^{\prime}, 2^{\prime}}=8.1 \mathrm{~Hz}, J_{3^{\prime}, 4^{\prime}}=\right.$ $9.30 \mathrm{~Hz}$ ) confirmed the trans-diaxial relationships between $\mathrm{H}-1 / \mathrm{H}^{-}$ 2 and $\mathrm{H}-3 / \mathrm{H}-4$ indicating the presence of an acetylated $\beta$-D-glucose unit. This was supported by correlations seen in the NOESY spectrum between the $\mathrm{H}-1^{\prime}$ and $\mathrm{H}-3^{\prime}, \mathrm{H}-1^{\prime}$ and $\mathrm{H}-5^{\prime}$ and $\mathrm{H}-2^{\prime}$ and $\mathrm{H}-4^{\prime}$ resonances.

As in previous compounds, the $\mathrm{C}-6^{\prime}$ resonance showed a correlation in the HMBC spectrum with the anomeric proton resonance at $\delta_{\mathrm{H}} 4.48\left(\mathrm{H}-1^{\prime \prime}\right)$ of $\beta$-D-arabinose. All resonances for this sugar could be assigned and the coupling constants of $J_{1^{\prime \prime}, 2^{\prime \prime}}=$ $6.6 \mathrm{~Hz}$ and $J_{3^{\prime \prime}, 4^{\prime \prime}}=3.5 \mathrm{~Hz}$ indicated trans-diaxial and axialequatorial relationships respectively, confirmed by correlations seen in the NOESY spectrum between the $\mathrm{H}-1^{\prime \prime} / \mathrm{H}-3^{\prime \prime}, \mathrm{H}-3^{\prime} / \mathrm{H}-4^{\prime \prime}, \mathrm{H}-$ $4^{\prime \prime} / \mathrm{H}-5^{\prime \prime} \beta$ and between $\mathrm{H}-1^{\prime \prime} / \mathrm{H}-5^{\prime \prime} \alpha$ resonances identified the sugar. The $\mathrm{C}-3^{\prime}$ resonance was seen to correlate with the anomeric proton resonance at $\delta_{\mathrm{H}} 4.53$ of the pentose sugar in the HMBC spectrum, which was assigned as $\mathrm{H}-1^{\prime \prime \prime}$, indicating the third sugar was linked to $\beta$-D-glucose at C-3'. The $J_{1^{\prime \prime \prime}, 2^{\prime \prime \prime}}=6.20 \mathrm{~Hz}$ and $J_{3^{\prime \prime \prime}, 4^{\prime \prime \prime}}=$ $7.80 \mathrm{~Hz}$ indicated that $\mathrm{H}-\mathrm{1}^{\prime \prime \prime} / \mathrm{H}-2^{\prime \prime \prime}$ and $\mathrm{H}-3^{\prime \prime \prime} / \mathrm{H}-4^{\prime \prime \prime}$ both have transdiaxial relationships, hence, the sugar was identified as $\beta$-D-xylose. This was confirmed by correlations seen in the NOESY spectrum between the $\mathrm{H}-1^{\prime \prime \prime} / \mathrm{H}-3^{\prime \prime \prime}$ and $\mathrm{H}-4^{\prime \prime \prime} / \mathrm{H}-2^{\prime \prime \prime}$ resonances.

$(R)$-5,7-Dihydroxy-8-methoxy-3-(4'-methoxybenzyl)-4-chroma none, eucosterol, $(17 S, 23 S)$-23,17-epoxy-3 $\beta, 28,29$-trihydroxy-27norlanost-8-en-24-one, 1, 2Ac, 3, 4 and 5 were evaluated against the NCI 60 developmental Therapeutics Program 60 cancer cell line screen at a single dose of $10^{-5} \mathrm{M}$. Details of the methodology of NCI-60 Human Tumour Cell Line Screen are described at http://dtp.nci.nih.gov/branches/btb/ivclsp.html. None of the compounds showed sufficient activity to progress to the five-dose assay although 5 showed $72.5 \%$ inhibition of the H522 non-small lung cell line. One dose mean graphs for the compounds screened are provided in the ESI (S.5 $\left.\dagger^{\dagger}\right)$.

This investigation produced typical Eucomis-type constituents, homoisoflavonoids and lanostane triterpenoid derivatives. The variability of constituents isolated from the Hyacinthaceae has been noted by us previously. ${ }^{4-6}$ Only two of the compounds isolated in this work had been reported to occur in this species previously, the common homoisoflavonoids 3,5,7-trihydroxy-3(4'-methoxybenzyl)-4-chromanone ${ }^{7}$ and 5,7-dihydroxy-3-(4'methoxybenzyl)-4-chromanone. ${ }^{8}$ Compounds 3,8 and 9 had the same spirocyclic triterpenoid skeleton as scillasponin $\mathrm{A},{ }^{\mathbf{1 0}}$ but instead of being a pentaglycoside, occurred as the free triterpenoid (3) or as the mono- (8) or di-glycosides (9). Compounds 10-14 differed from related compounds isolated previously in that the C-28 methyl group was not oxidised, and the sugars differed. Rhamnopyranosyl sugars found in compounds isolated previously from the Japanese collection ${ }^{9}$ were not found in this collection from its natural habitat.

\section{Experimental section}

\section{General experiment procedures}

1D and 2D NMR spectra were recorded in $\mathrm{CDCl}_{3}$ on a $500 \mathrm{MHz}$ Bruker AVANCE NMR instrument at room temperature at the
University of Surrey and those of the acetylated triterpenoid glycosides were recorded on a $950 \mathrm{MHz}$ Bruker AVANCE NMR instrument at the David $H$. Murdock Research Institute (DHMRI), North Carolina Research Campus (NCRC) in Kannapolis, North Carolina. The chemical shifts $(\delta)$ are expressed in ppm and were referenced to the solvent resonances at 7.26 and $77.23 \mathrm{ppm}$ for $\mathrm{CDCl}_{3}, 4.87$ and 49.15 for $\mathrm{CD}_{3} \mathrm{OD}$ for ${ }^{1} \mathrm{H}$ and ${ }^{13} \mathrm{C}$ NMR analysis respectively. The ESI mass spectra were recorded on a Bruker MicroToF mass spectrometer using an Agilent 1100 HPLC to introduce samples (University of Oxford). The optical rotations were determined in $\mathrm{CHCl}_{3}$ on a JASCO P1020 polarimeter. The FTIR spectra were recorded using a Perkin-Elmer (2000) spectrometer.

\section{Plant material}

Bulbs of Eucomis bicolor (1.5 kg) were collected from the Drakensberg foothills, South Africa during January 2008. A voucher specimen has been lodged for verification purposes (N. Crouch 1157, NH).

\section{Extraction and isolation of compounds}

The whole bulbs of Eucomis bicolor (1.5 kg) were air-dried, chopped into smaller pieces and extracted with methylene chloride and methanol using a shaker for $48 \mathrm{~h}$ at room temperature. The extract was then filtered and the solvent was removed under reduced pressure to yield the methylene chloride extract (26.31 g) and the methanol extract (104.87 g). Column chromatography over silica gel (Merck 9385) using a $5 \mathrm{~cm}$ diameter gravity column, collecting fractions $(75 \mathrm{ml}$ each) using a methylene chloride/methanol step gradient starting with $100 \%$ methylene chloride and gradually increasing the methanol concentration to $100 \%$. Final purification was undertaken using $1 \mathrm{~cm}$ diameter gravity column. Full details are provided in the ESI (S.2†).

The methylene chloride extract yielded $(R)$-5,7-dihydroxy-8methoxy-3-(4'-methoxybenzyl)-4-chromanone (6.5 mg), 3,5,7trihydroxy-3-(4'-methoxybenzyl)-4-chromanone (7.2 mg) and $(R)$ 5,7-dihydroxy-3-(4'-methoxybenzyl)-4-chromanone (7.9 $\mathrm{mg}$ ), eucosterol (10.2 mg), $(17 S, 23 S)$-17,23-epoxy-3 $\beta, 28,29$-trihydrox27-norlanost-8-en-24-one (3.2 mg), 15-deoxoeucosterol (8.2 $\mathrm{mg})$ and 3-dehydro-15-deoxoeucosterol $(8.2 \mathrm{mg})$ and five novel compounds, 1 ( $8.5 \mathrm{mg})$, compound 2 which was acetylated to give compound $2 \mathrm{Ac}(2.8 \mathrm{mg}), 3(3.3 \mathrm{mg}), \mathbf{4}(3.6 \mathrm{mg})$ and 5 (2.5 $\mathrm{mg})$. The methanol extract yielded $(R)-5,7-t r i h y d r o x y-3-\left(4^{\prime}-\right.$ hydroxybenzyl)-4-chromanone $(8.2 \mathrm{mg})$ and nine novel lanosterol glycosides which were isolated as their acetate derivatives after acetylation of a complex mixture to yield 6Ac (1.9 mg), 7Ac (1.2 mg), 8Ac (1.8 mg), 9Ac (1.1 mg) 10Ac (2.3 mg), 11Ac (0.8 mg), 12Ac $(2.1 \mathrm{mg})$, 13Ac $(1.7 \mathrm{mg})$ and 14Ac (1.4 mg). A detailed isolation scheme is given in the ESI (S.2 $\dagger$ ). Full NMR data for compounds 1-5 and acetates of 2, and 6-14 are given in Tables $1-5$ and spectra are given in the ESI (S.4†).

(17S)-24,25,26,27,29-Pentanor-3-oxo-lanost-8-en-23,17 $\alpha$-olide (1). Pale yellow powder; $[\alpha]_{\mathrm{D}}^{23.6}+29.15\left(c 0.0094, \mathrm{CHCl}_{3}\right)$; IR $\nu_{\max }$ $(\mathrm{NaCl}) \mathrm{cm}^{-1} 2953,2923 \mathrm{~cm}^{-1}$ (C-H stretches) and 1767, 1708 
Table $4{ }^{13} \mathrm{C}$ NMR $(237 \mathrm{MHz})$ chemical shifts for compounds $6 \mathrm{Ac}-7 \mathrm{Ac}, 10 \mathrm{Ac}-12 \mathrm{Ac}\left(\mathrm{CDCl}_{3}\right)$

\begin{tabular}{|c|c|c|c|c|c|}
\hline No & 6Ac & 7Ac & $10 A c$ & 11Ac & 12Ac \\
\hline 1 & $35.8 \mathrm{CH}_{2}$ & $35.6 \mathrm{CH}_{2}$ & $36.0 \mathrm{CH}_{2}$ & $36.0 \mathrm{CH}_{2}$ & $35.9 \mathrm{CH}_{2}$ \\
\hline 2 & $27.3 \mathrm{CH}_{2}$ & $27.2 \mathrm{CH}_{2}$ & $27.2 \mathrm{CH}_{2}$ & $27.1 \mathrm{CH}_{2}$ & $27.4 \mathrm{CH}_{2}$ \\
\hline 3 & $90.1 \mathrm{CH}$ & $89.9 \mathrm{CH}$ & $90.3 \mathrm{CH}$ & $90.3 \mathrm{CH}$ & $90.3 \mathrm{CH}$ \\
\hline 4 & $42.3 \mathrm{C}$ & $42.3 \mathrm{C}$ & $42.4 \mathrm{C}$ & $42.4 \mathrm{C}$ & $42.3 \mathrm{C}$ \\
\hline 5 & $51.4 \mathrm{CH}$ & $51.1 \mathrm{CH}$ & $52.2 \mathrm{CH}$ & $51.9 \mathrm{CH}$ & $51.3 \mathrm{CH}$ \\
\hline 6 & $19.5 \mathrm{CH}_{2}$ & $19.4 \mathrm{CH}_{2}$ & $19.7 \mathrm{CH}_{2}$ & $19.5 \mathrm{CH}_{2}$ & $19.6 \mathrm{CH}_{2}$ \\
\hline 7 & $26.5 \mathrm{CH}_{2}$ & $26.3 \mathrm{CH}_{2}$ & $26.8 \mathrm{CH}_{2}$ & $26.8 \mathrm{CH}_{2}$ & $26.5 \mathrm{CH}_{2}$ \\
\hline 8 & $133.4 \mathrm{C}$ & $133.3 \mathrm{C}$ & $134.2 \mathrm{C}$ & $134.3 \mathrm{C}$ & $133.5 \mathrm{C}$ \\
\hline 9 & $136.0 \mathrm{C}$ & $136.0 \mathrm{C}$ & $135.7 \mathrm{C}$ & $135.7 \mathrm{C}$ & $135.9 \mathrm{C}$ \\
\hline 10 & $37.4 \mathrm{C}$ & $37.4 \mathrm{C}$ & $37.1 \mathrm{C}$ & $37.0 \mathrm{C}$ & $37.4 \mathrm{C}$ \\
\hline 11 & $20.5 \mathrm{CH}_{2}$ & $20.5 \mathrm{CH}_{2}$ & $21.0 \mathrm{CH}_{2}$ & $21.2 \mathrm{CH}_{2}$ & $20.5 \mathrm{CH}_{2}$ \\
\hline 12 & $23.0 \mathrm{CH}_{2}$ & $22.9 \mathrm{CH}_{2}$ & $25.1 \mathrm{CH}_{2}$ & $25.1 \mathrm{CH}_{2}$ & $23.1 \mathrm{CH}_{2}$ \\
\hline 13 & $47.8 \mathrm{C}$ & $47.6 \mathrm{C}$ & $48.7 \mathrm{C}$ & $48.8 \mathrm{C}$ & $47.6 \mathrm{C}$ \\
\hline 14 & $57.9 \mathrm{C}$ & $57.9 \mathrm{C}$ & $50.9 \mathrm{C}$ & $50.8 \mathrm{C}$ & $57.9 \mathrm{C}$ \\
\hline 15 & $215.6 \mathrm{C}$ & $215.7 \mathrm{C}$ & $31.9 \mathrm{CH}_{2}$ & $31.9 \mathrm{CH}_{2}$ & $215.6 \mathrm{C}$ \\
\hline 16 & $51.9 \mathrm{CH}_{2}$ & $51.7 \mathrm{CH}_{2}$ & $39.9 \mathrm{CH}_{2}$ & $39.8 \mathrm{CH}_{2}$ & $52.1 \mathrm{CH}_{2}$ \\
\hline 17 & $91.2 \mathrm{C}$ & $91.2 \mathrm{C}$ & $97.3 \mathrm{C}$ & $97.3 \mathrm{C}$ & $91.3 \mathrm{C}$ \\
\hline 18 & $20.7 \mathrm{CH}_{3}$ & $20.4 \mathrm{CH}_{3}$ & $19.2 \mathrm{CH}_{3}$ & $19.5 \mathrm{CH}_{3}$ & $20.7 \mathrm{CH}_{3}$ \\
\hline 19 & $19.1 \mathrm{CH}_{3}$ & $19.6 \mathrm{CH}_{3}$ & $18.9 \mathrm{CH}_{3}$ & $19.2 \mathrm{CH}_{3}$ & $19.0 \mathrm{CH}_{3}$ \\
\hline 20 & $43.5 \mathrm{CH}$ & $43.3 \mathrm{CH}$ & $44.0 \mathrm{CH}$ & $43.7 \mathrm{CH}$ & $43.2 \mathrm{CH}$ \\
\hline 21 & $17.4 \mathrm{CH}_{3}$ & $17.3 \mathrm{CH}_{3}$ & $17.4 \mathrm{CH}_{3}$ & $17.4 \mathrm{CH}_{3}$ & $17.3 \mathrm{CH}_{3}$ \\
\hline 22 & $37.2 \mathrm{CH}_{2}$ & $36.7 \mathrm{CH}_{2}$ & $37.1 \mathrm{CH}_{2}$ & $37.0 \mathrm{CH}_{2}$ & $37.0 \mathrm{CH}_{2}$ \\
\hline 23 & $81.3 \mathrm{CH}$ & $81.8 \mathrm{CH}$ & $81.8 \mathrm{CH}$ & $81.6 \mathrm{CH}$ & $81.6 \mathrm{CH}$ \\
\hline 24 & $212.2 \mathrm{C}$ & $212.2 \mathrm{C}$ & $213.6 \mathrm{C}$ & $213.6 \mathrm{C}$ & $212.2 \mathrm{C}$ \\
\hline 25 & $32.7 \mathrm{CH}_{2}$ & $32.5 \mathrm{CH}_{2}$ & $32.2 \mathrm{CH}_{2}$ & $32.4 \mathrm{CH}_{2}$ & $32.5 \mathrm{CH}_{2}$ \\
\hline 26 & $7.6 \mathrm{CH}_{3}$ & $7.5 \mathrm{CH}_{3}$ & $7.8 \mathrm{CH}_{3}$ & $7.6 \mathrm{CH}_{3}$ & $7.4 \mathrm{CH}_{3}$ \\
\hline 28 & $22.6 \mathrm{CH}_{3}$ & $22.7 \mathrm{CH}_{3}$ & $22.3 \mathrm{CH}_{3}$ & $22.5 \mathrm{CH}_{3}$ & $22.6 \mathrm{CH}_{3}$ \\
\hline 29 & $65.7 \mathrm{CH}_{2}$ & $65.5 \mathrm{CH}_{2}$ & $65.5 \mathrm{CH}_{2}$ & $65.5 \mathrm{CH}_{2}$ & $65.8 \mathrm{CH}_{2}$ \\
\hline 30 & $23.9 \mathrm{CH}_{3}$ & $23.7 \mathrm{CH}_{3}$ & $25.9 \mathrm{CH}_{3}$ & $25.8 \mathrm{CH}_{3}$ & $23.9 \mathrm{CH}_{3}$ \\
\hline Glu $1^{\prime}$ & $102.9 \mathrm{CH}$ & $102.7 \mathrm{CH}$ & $103.1 \mathrm{CH}$ & $102.9 \mathrm{CH}$ & $103.7 \mathrm{CH}$ \\
\hline $2^{\prime}$ & $71.9 \mathrm{CH}$ & $72.7 \mathrm{CH}$ & $71.9 \mathrm{CH}$ & $71.7 \mathrm{CH}$ & $71.8 \mathrm{CH}$ \\
\hline $3^{\prime}$ & $73.2 \mathrm{CH}$ & $80.4 \mathrm{CH}$ & $73.1 \mathrm{CH}$ & $73.1 \mathrm{CH}$ & $73.2 \mathrm{CH}$ \\
\hline $4^{\prime}$ & $69.2 \mathrm{CH}$ & $69.2 \mathrm{CH}$ & $68.8 \mathrm{CH}$ & $69.0 \mathrm{CH}$ & $68.8 \mathrm{CH}$ \\
\hline $5^{\prime}$ & $73.6 \mathrm{CH}$ & $73.4 \mathrm{CH}$ & $71.8 \mathrm{CH}$ & $73.3 \mathrm{CH}$ & $71.9 \mathrm{CH}$ \\
\hline $6^{\prime}$ & $67.8 \mathrm{CH}_{2}$ & $67.6 \mathrm{CH}_{2}$ & $62.4 \mathrm{CH}_{2}$ & $67.3 \mathrm{CH}_{2}$ & $62.3 \mathrm{CH}_{2}$ \\
\hline Arab $1^{\prime \prime}$ & $100.6 \mathrm{CH}$ & $100.3 \mathrm{CH}$ & - & $100.4 \mathrm{CH}$ & - \\
\hline $2^{\prime \prime}$ & $69.2 \mathrm{CH}$ & $69.0 \mathrm{CH}$ & - & $69.0 \mathrm{CH}$ & - \\
\hline $3^{\prime \prime}$ & $70.3 \mathrm{CH}$ & $70.0 \mathrm{CH}$ & - & $70.0 \mathrm{CH}$ & - \\
\hline $4^{\prime \prime}$ & $67.6 \mathrm{CH}$ & $67.4 \mathrm{CH}$ & - & $67.4 \mathrm{CH}$ & - \\
\hline $5^{\prime \prime}$ & $63.1 \mathrm{CH}_{2}$ & $62.8 \mathrm{CH}_{2}$ & - & $62.9 \mathrm{CH}_{2}$ & - \\
\hline Xyl $1^{\prime \prime \prime}$ & - & $101.1 \mathrm{CH}$ & - & - & - \\
\hline $2^{\prime \prime \prime}$ & - & $70.0 \mathrm{CH}$ & - & - & - \\
\hline $3^{\prime \prime \prime}$ & - & $70.7 \mathrm{CH}$ & - & - & - \\
\hline $4^{\prime \prime \prime}$ & - & $68.6 \mathrm{CH}$ & - & - & - \\
\hline $5^{\prime \prime \prime}$ & - & $61.7 \mathrm{CH}$ & - & - & - \\
\hline OAc & $\begin{array}{l}20.6,21.2,21.3 \\
20.9,20.9,21.1,20.9\end{array}$ & $\begin{array}{l}20.6,21.2,21.3 \\
20.9,21.1,20.9 \\
21.2,21.1\end{array}$ & $\begin{array}{l}20.5,20.9, \\
20.9,21.0,21.3\end{array}$ & $\begin{array}{l}20.6,21.2,21.3 \\
20.9,20.9 \\
21.1,20.9\end{array}$ & $\begin{array}{l}20.5,20.7, \\
20.8,20.8,21.0\end{array}$ \\
\hline OAc & $\begin{array}{l}170.5,169.7,170.3 \\
170.6,169.5,169.4, \\
171.3\end{array}$ & $\begin{array}{l}170.5,169.7,170.3 \\
170.6,169.5,169.4 \\
171.3,169.1,170.1\end{array}$ & $\begin{array}{l}170.6,169.4, \\
170.9,169.6, \\
170.8\end{array}$ & $\begin{array}{l}170.5,169.7 \\
170.3,170.6, \\
169.5,169.4,171.3\end{array}$ & $\begin{array}{l}\text { 170.6, 169.4, 171.2, } \\
169.6,170.8\end{array}$ \\
\hline
\end{tabular}

$\mathrm{cm}^{-1}\left(\mathrm{C}=\mathrm{O}\right.$ stretch); HRESIMS $m / z$ 407.2570 $[\mathrm{M}+\mathrm{Na}]^{+}$(calc. for $\mathrm{C}_{25} \mathrm{H}_{36} \mathrm{O}_{3} \mathrm{Na}$ 407.2562). NMR data are given in Tables 1 and 2.

(17S)-24,25,26,27-Tetranor-3 $\beta, 28,29$-triacetoxy-lanost-8-en23,17 $\alpha$-olide (2Ac). Colourless oil; $[\alpha]_{\mathrm{D}}^{23.6} 40.67$ (c 0.0009, $\left.\mathrm{CHCl}_{3}\right) ; \mathrm{IR} \nu_{\max }(\mathrm{NaCl}) \mathrm{cm}^{-1} 2916,2849(\mathrm{C}-\mathrm{H}$ stretch) and 1778, $1738\left(\mathrm{C}=\mathrm{O}\right.$ stretch); HRESIMS $m / z 581.3096[\mathrm{M}+\mathrm{Na}]^{+}$ (calc. for $\mathrm{C}_{32} \mathrm{H}_{46} \mathrm{O}_{8} \mathrm{Na} 581.3090$ ). NMR data are given in Tables 1 and 2 .
$(17 S, 23 S)$-17 $\alpha, 23-E p o x y-29-h y d r o x y l a n o s t-8-e n-3-o n-27,23-o l i d e$ (3). Colourless oil; $[\alpha]_{\mathrm{D}}^{23.6}+11.25\left(c 0.0032, \mathrm{CHCl}_{3}\right)$; IR $\nu_{\max }(\mathrm{NaCl})$ $\mathrm{cm}^{-1}$ 2923, 2853 (C-H stretch) 3467 (O-H stretch) and 1772, 1701 $\left(\mathrm{C}=\mathrm{O}\right.$ stretch); HRESIMS $\mathrm{m} / \mathrm{z} 507.3078[\mathrm{M}+\mathrm{Na}]^{+}$(calc. for $\mathrm{C}_{30} \mathrm{H}_{44} \mathrm{O}_{5} \mathrm{Na}$ 507.3086). NMR data are given in Tables 1 and 2.

3 $\beta, 23 S, 24 \varepsilon, 29-T e t r a h y d r o x y-27-n o r l a n o s t a-8-16-d i e n e-15-o n e$ (4). Pale Yellow oil; $[\alpha]_{\mathrm{D}}^{23.6}+25.00\left(c 0.0008, \mathrm{CHCl}_{3}\right)$; IR $\nu_{\max }$ $(\mathrm{NaCl}) \mathrm{cm}^{-1}$ 2932, 2875 (C-H stretch), 3399 (O-H stretch) and 
Table $5{ }^{13} \mathrm{C}$ NMR $(237 \mathrm{MHz})$ chemical shifts for compounds $8 \mathrm{Ac}, 9 \mathrm{Ac}, 13 \mathrm{Ac}$ and $14 \mathrm{Ac}\left(\mathrm{CDCl}_{3}\right)$

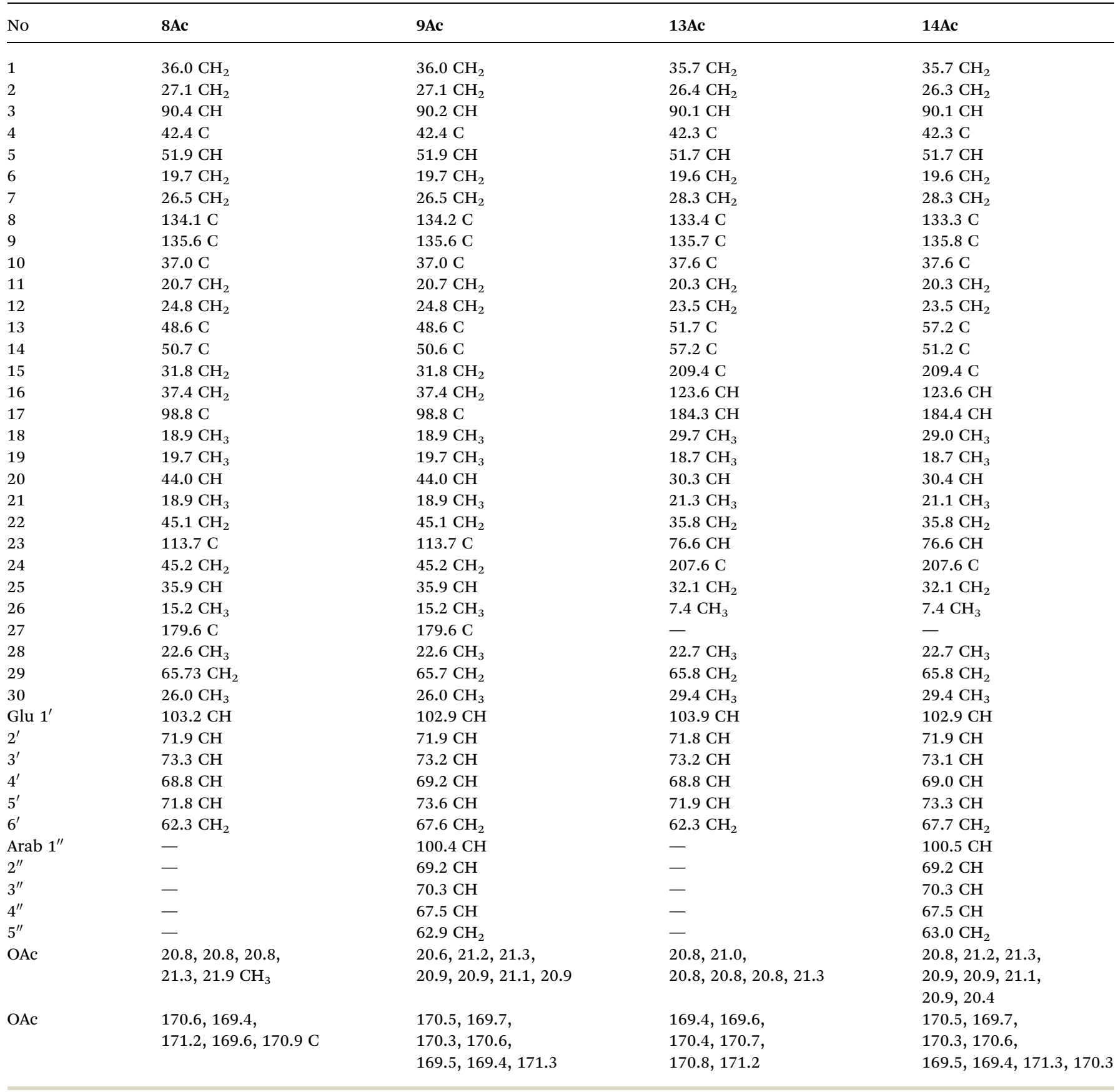

$1692\left(\mathrm{C}=\mathrm{O}\right.$ stretch); HRESIMS $m / z 497.3225[\mathrm{M}+\mathrm{Na}]^{+}$(calc. for $\mathrm{C}_{29} \mathrm{H}_{46} \mathrm{O}_{5} \mathrm{Na}$ 497.3243). NMR data are given in Tables 1 and 2.

3ß,23S,29-Trihydroxy-27-norlanost-8,16-diene-15,24-dione (5). Colourless oil; $[\alpha]_{\mathrm{D}}^{23.6}=+79.8\left(c 0.0020, \mathrm{CHCl}_{3}\right)$; IR $\nu_{\max }(\mathrm{NaCl})$ $\mathrm{cm}^{-1} 3433(\mathrm{O}-\mathrm{H}$ stretch) $3402(\mathrm{O}-\mathrm{H}$ stretch) and $1736(\mathrm{C}=\mathrm{O}$ stretch); HRESIMS $m / z 495.3071[\mathrm{M}+\mathrm{Na}]^{+}$(calc. for $\mathrm{C}_{29} \mathrm{H}_{44} \mathrm{O}_{5} \mathrm{Na}$ 495.3086). NMR data are given in Tables 1 and 2 .

$23 S, 29-D i a c e t o x y-3 \beta$ - $\left[2^{\prime}, 3^{\prime}, 4^{\prime}, 6^{\prime}\right.$-tetra- $O$-acetyl-O- $\beta$-D-glucopyranoside]-27-norlanosta-8,16-diene-15,24-dione (6Ac). Clear gum; $[\alpha]_{\mathrm{D}}^{23.6}=+12.2\left(c=0.0007 \mathrm{~g} \mathrm{ml}^{-1}, \mathrm{CHCl}_{3}\right) ; \mathrm{IR} \nu_{\max }(\mathrm{NaCl}) \mathrm{cm}^{-1}$ 2925, 2878 (C-H stretch), $1240 \mathrm{~cm}^{-1}$ (C-O stretch) and $1753 \mathrm{~cm}^{-1}$
$\left(\mathrm{C}=\mathrm{O}\right.$ stretch); HRESIMS $\mathrm{m} / \mathrm{z}$ 909.4254 $[\mathrm{M}+\mathrm{Na}]^{+}$(calc. for $\mathrm{C}_{47} \mathrm{H}_{66} \mathrm{O}_{16} \mathrm{Na} 909.4243$, 909.4248). NMR data are given in Tables 3 and 4 .

$(17 S, 23 S)$-29-Acetoxy-23,17-epoxy-3 $\beta$-[2 $2^{\prime}, 3^{\prime}, 4^{\prime}$-tri- $O$-acetyl- $O$ - $\beta$ D-glucopyranoside- $\left(1^{\prime \prime} \rightarrow 6^{\prime}\right)-2^{\prime \prime}, 3^{\prime \prime}, 4^{\prime \prime}$-tri- $O$-acetyl- $O$ - $\beta$-D-arabinopyranosyl]-lanost-8-en-23,27-olide (7Ac). Clear gum; $[\alpha]_{\mathrm{D}}^{23.6}=$ $+11.3\left(c=0.0007 \mathrm{~g} \mathrm{ml}^{-1}, \mathrm{CHCl}_{3}\right)$; IR $\nu_{\max }(\mathrm{NaCl}) \mathrm{cm}^{-1} 2925,2878$ (C- H stretch), 1221 and $1248 \mathrm{~cm}^{-1}$ (C-O stretch) and 1753 $\mathrm{cm}^{-1}\left(\mathrm{C}=\mathrm{O}\right.$ stretch). HRESIMS $m / z$ 1125.4865 $[\mathrm{M}+\mathrm{Na}]^{+}$(calc. for $\mathrm{C}_{56} \mathrm{H}_{78} \mathrm{O}_{22} \mathrm{Na}$ 1125.4882). NMR data are given in Tables 3 and 4 . 
$(17 S, 23 S)$-29-Acetoxy-23,17-epoxy-3 $\beta-\left[2^{\prime}, 3^{\prime}, 4^{\prime} 6^{\prime}\right.$-tetra-O-acetyl$O$ - $\beta$-D-glucopyranoside]-lanost-8-en-23,27-olide (8Ac). Clear gum; $[\alpha]_{\mathrm{D}}^{23.6}=+10.5\left(c=0.0012 \mathrm{~g} \mathrm{ml}^{-1}, \mathrm{CHCl}_{3}\right), \mathrm{IR} \nu_{\max }(\mathrm{NaCl})$ $\mathrm{cm}^{-1}$ 2922, 2847 (C-H stretch), $1225 \mathrm{~cm}^{-1}$ (C-O stretch) and $1755 \mathrm{~cm}^{-1}$ ( $\mathrm{C}=\mathrm{O}$ stretch). HRESIMS: $[\mathrm{M}]^{+}$not observed. NMR data are given in Tables 3 and 5 .

$(17 S, 23 S)$-29-Acetoxy-23,17-epoxy-3 $\beta$-[2 $2^{\prime}, 3^{\prime}, 4^{\prime}$-tri- $O$-acetyl-O- $\beta$ D-glucopyranoside-( $\left.1^{\prime \prime} \rightarrow 6^{\prime}\right)-2^{\prime \prime}, 3^{\prime \prime}, 4^{\prime \prime}$-tri- $O$-acetyl- $O$ - $\beta$-L-arabinopyranosyl]-lanost-8-en-23,27-olide (9Ac). Clear gum; $[\alpha]_{\mathrm{D}}^{23.6}=$ $+11.3\left(c=0.0007 \mathrm{~g} \mathrm{ml}^{-1}, \mathrm{CHCl}_{3}\right) ; \mathrm{IR} \nu_{\max }(\mathrm{NaCl}) \mathrm{cm}^{-1} 2925,2878$ (C-H stretch), 1221 and $1248 \mathrm{~cm}^{-1}$ (C-O stretch) and $1753 \mathrm{~cm}^{-1}$ ( $\mathrm{C}=\mathrm{O}$ stretch). HRESIMS $\mathrm{m} / \mathrm{z}$ 1097.4880 $[\mathrm{M}+\mathrm{Na}]^{+}$(calc. for $\mathrm{C}_{55} \mathrm{H}_{78} \mathrm{O}_{21} \mathrm{Na}$ 1097.4933). NMR data are given in Tables 3 and 5.

$(17 S, 23 S)$-29-Acetoxy-23,17-epoxy-3 $\beta$ - $\left[2^{\prime}, 3^{\prime}, \mathbf{4}^{\prime} 6^{\prime}\right.$-tetra- $O$-acetyl$O$ - $\beta$-D-glucopyranoside]-27-norlanost-8-en-24-one (10Ac). Clear gum; $[\alpha]_{\mathrm{D}}^{23.6}=+12.4\left(c=0.0011 \mathrm{~g} \mathrm{ml}^{-1}, \mathrm{CHCl}_{3}\right) ; \mathrm{IR} \nu_{\max }(\mathrm{NaCl})$ $\mathrm{cm}^{-1} 2922,2857 \mathrm{~cm}^{-1}$ (C-H stretches), $1229 \mathrm{~cm}^{-1}$ (C-O stretch) and $1744 \mathrm{~cm}^{-1}\left(\mathrm{C}=\mathrm{O}\right.$ stretch); HRESIMS $\mathrm{m} / z$ 830.4421 $[\mathrm{M}]^{+}$ (calc. for $\mathrm{C}_{45} \mathrm{H}_{66} \mathrm{O}_{14}$ 830.4453). NMR data are given in Tables 3 and 4 .

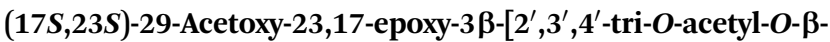
D-glucopyranoside- $\left(1^{\prime \prime} \rightarrow 6^{\prime}\right)-2^{\prime \prime}, 3^{\prime \prime}, 4^{\prime \prime}$-tri- $O$-acetyl-O- $\beta$-D-arabinopyranosyl]-27-norlanost-8-en-24-one (11Ac). Clear gum; $[\alpha]_{\mathrm{D}}^{23.6}=$ $+19.2\left(c=0.0005 \mathrm{~g} \mathrm{ml}^{-1}, \mathrm{CHCl}_{3}\right) ; \mathrm{IR} \nu_{\max }(\mathrm{NaCl}) \mathrm{cm}^{-1} 2937,2868$ $\mathrm{cm}^{-1}$ (C- H stretches), $1223 \mathrm{~cm}^{-1}$ (C-O stretch) and $1749 \mathrm{~cm}^{-1}$ $\left(\mathrm{C}=\mathrm{O}\right.$ stretch); HRESIMS $[\mathrm{M}]^{+}$not observed. Base peak at $\mathrm{m} / \mathrm{z}$ 587.1579, $\left[\mathrm{C}_{23} \mathrm{H}_{31} \mathrm{O}_{16} \mathrm{Na}+\mathrm{H}\right]^{+}$was observed. NMR data are provided in Tables 3 and 4.

$(17 S, 23 S)$-29-Acetoxy-23,17-epoxy-3 $\beta$-[2 $2^{\prime}, 3^{\prime}, 4^{\prime} 6^{\prime}$-tetra-O-acetyl$O$ - $\beta$-D-glucopyranoside]-27-norlanost-8-ene-15,24-dione (12Ac). Clear gum; $[\alpha]_{\mathrm{D}}^{23.6}=+22.9\left(c=0.0016 \mathrm{~g} \mathrm{ml}^{-1}, \mathrm{CHCl}_{3}\right)$; IR $\nu_{\max }$ (NaCl) cm $\mathrm{cm}^{-1} 2921,2847 \mathrm{~cm}^{-1}$ (C- H stretches), $1222 \mathrm{~cm}^{-1}$ (C-O stretch) and $1748 \mathrm{~cm}^{-1}(\mathrm{C}=\mathrm{O}$ stretch $)$; HRESIMS $\mathrm{m} / z 867.4147$ $[\mathrm{M}+\mathrm{Na}]^{+}$(calc. for $\mathrm{C}_{45} \mathrm{H}_{64} \mathrm{O}_{15} \mathrm{Na}$ 867.4143). NMR data are given in Tables 3 and 4.

$(17 S, 23 S)$-29-Acetoxy-23,17-epoxy-3 $\beta$-[2 $2^{\prime}, 3^{\prime}, 4^{\prime}$-tri- $O$-acetyl- $O$ - $\beta$ D-glucopyranoside-( $\left(1^{\prime \prime} \rightarrow 6^{\prime}\right)-2^{\prime \prime}, 3^{\prime \prime}, 4^{\prime \prime}$-tri- $O$-acetyl- $O$ - $\beta$-L-arabinopyranosyl]-27-norlanost-8-en-15,24-dione) (13Ac). Clear gum; $[\alpha]_{\mathrm{D}}^{23.6}=+25.4\left(c=0.0011 \mathrm{~g} \mathrm{ml}^{-1}, \mathrm{CHCl}_{3}\right) ; \mathrm{IR} \nu_{\max }(\mathrm{NaCl}) \mathrm{cm}^{-1}$ 2922, $2848 \mathrm{~cm}^{-1}$ (C- H stretches), $1225 \mathrm{~cm}^{-1}$ (C-O stretch) and $1755 \mathrm{~cm}^{-1}\left(\mathrm{C}=\mathrm{O}\right.$ stretch); HRESIMS $\mathrm{m} / z$ 1083.4739 $[\mathrm{M}+\mathrm{Na}]^{+}$ (calc. for $\mathrm{C}_{54} \mathrm{H}_{76} \mathrm{O}_{21} \mathrm{Na}$ 1083.4776). NMR data are provided in Tables 3 and 5.

$(17 S, 23 S)$-29-Acetoxy-23,17-epoxy-3 $\beta$-[2 $2^{\prime}, 3^{\prime}, \mathbf{4}^{\prime}$-tri-O-acetyl-O- $\beta$ D-glucopyranoside- $\left(1^{\prime \prime} \rightarrow 6^{\prime}\right)-2^{\prime \prime}, 3^{\prime \prime}, 4^{\prime \prime}$-tri- $O$-acetyl- $O$-L-D-arabino-

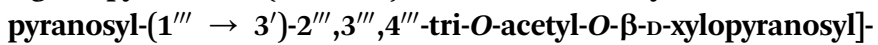
27-norlanost-8-ene-15,24-dione (14Ac). Clear gum; $[\alpha]_{\mathrm{D}}^{23.6}=$ $+24.5\left(c=0.0007 \mathrm{~g} \mathrm{ml}^{-1}, \mathrm{CHCl}_{3}\right), \mathrm{IR} \nu_{\max }(\mathrm{NaCl}) \mathrm{cm}^{-1} 2937,2868$ (C-H stretch) and $1223 \mathrm{~cm}^{-1}$ (C-O stretch) and $1749 \mathrm{~cm}^{-1}(\mathrm{C}=$ $\mathrm{O}$ stretch). HRESIMS $[\mathrm{M}]^{+}$not observed. Base peak at $\mathrm{m} / \mathrm{z}$ 803.2235 $\left[\mathrm{C}_{32} \mathrm{H}_{43} \mathrm{O}_{22} \mathrm{Na}+\mathrm{H}\right.$ requires 803.2221] was observed. NMR data are provided in Tables 3 and 5.

\section{Acknowledgements}

This work was supported by the EPSRC Research Council [grant number EP/P50404X] and the PMI2 Project funded by the UK
Department for Business, Innovation and Skills (BIS) for the benefit of the United States Higher Education Sector and the UK Higher Education Sector (grant NPF204, awarded to Malcolm von Schantz). The views expressed are not necessarily those of BIS, nor British Council. This grant funded a visit by ML to the David H. Murdock Research Institute, Kannapolis, USA to record NMR spectra on the $950 \mathrm{MHz}$ NMR instrument and we thank Dr Kevin Knagge for his assistance. Financial support by CNRS, Conseil Regional Champagne Ardenne, Conseil General de la Marne, Ministry of Higher Education and Research (MESR) and EU-programme FEDER to the PIAneT CPER project is gratefully acknowledged. We thank Mr Colin Sparrow of the Mass Spectrometry Research Facility, Department of Chemistry, University of Oxford for MS analysis. The authors wish to acknowledge The Developmental Therapeutics Program (DTP) of the National Cancer Institute of the United States (U.S.A) for performing the screening of compounds.

\section{Notes and references}

1 M. Mander, Marketing of indigenous medicinal plants in South Africa. A case study in KwaZulu-Natal, FAO, UN, Rome, 1998, p. 151.

2 D. Von Ahlefeldt, N. R. Crouch, G. Nichols, R. Symmonds, S. McKean, H. Sibiya and M. P. Cele, Medicinal Plants Traded on South Africa's Eastern Seaboard, Ethekwini Park's Department and University of Natal, Durban, South Africa, 2003.

3 C. Koorbanally, N. R. Crouch, A. Langlois, K. Du Toit, D. A. Mulholland and S. E. Drewes, S. Afr. J. Bot., 2006, 72, 428-433.

4 N. Moodley, D. A. Mulholland and N. R. Crouch, J. Nat. Prod., 2004, 67, 918-920.

5 D. A. Mulholland, N. R. Crouch, C. Koorbanally, N. Moodley and T. Pohl, Biochem. Syst. Ecol., 2006, 34, 251-255.

6 D. A. Mulholland, S. L. Schwikkard and N. R. Crouch, Nat. Prod. Rep., 2013, 30, 1153-1266.

7 P. Böhler and C. Tamm, Tetrahedron Lett., 1967, 8, 3479-4483.

8 W. Heller, P. Andermatt, W. Schaad and C. Tamm, Helv. Chim. Acta, 1976, 59, 2048-2058.

9 Y. Mimaki, H. Nishino, K. Ori, M. Kuroda, T. Matsui and Y. Sashida, Chem. Pharm. Bull., 1994, 42, 327-332.

10 Y. Mimaki, K. Ori, S. Kubo, Y. Sashida, T. Nikaido, L. G. Song and T. Ohmoto, Chem. Lett., 1992, 9, 1863-1866.

11 N. R. Crouch, V. Bangani and D. A. Mulholland, Phytochemistry, 1999, 51, 943-946.

12 J. Mutanyatta, B. G. Matapa, D. Shushu and B. M. Abegaz, Phytochemistry, 2003, 62, 797-804.

13 N. Koorbanally, N. R. Crouch, A. Harilal, B. Pillay and D. A. Mulholland, Biochem. Syst. Ecol., 2006, 34, 114-118.

14 R. E. Finckh and C. Tamm, Experientia, 1970, 26, 472-473.

15 N. Moodley, N. R. Crouch, D. A. Mulholland, D. Slade and D. Ferreira, S. Afr. J. Bot., 2006, 72, 517-520.

16 W. T. L. Sidwell, C. Tamm and R. Zeigler, J. Am. Chem. Soc., 2003, 97, 3518-3519.

17 F. Adinolfi, G. Barone, M. Belardini, R. Lanzetta, G. Laonigro and M. Parilli, Phytochemistry, 1984, 23, 2091-2093. 
18 M. Sholichon, K. Miyahara and T. Kawasaki, Heterocycles, 1982, 17, 251-257.

19 C. Koorbanally, S. Sewjee, D. A. Mulholland, N. R. Crouch and A. Dold, Phytochemistry, 2007, 68, 2753-2756.

20 R. Lanzetta, G. Laonigro, M. Parrilli and E. Breitmaier, Can. J. Chem., 1984, 62, 2874-2878.

21 J. M. Nuzillard, Chin. J. Chem., 2003, 21, 1263-1267.

22 J. M. Nuzillard, Logic for Structure Determination Software: http://www.univ-reims.fr/LSD, 2010.
23 M. Adinolfi, M. Corsaro, R. Lanzetta, A. Mancino, L. Mangoni and M. Parrilli, Phytochemicals, 1993, 34, 773778.

24 R. Ziegler and C. Tamm, Helv. Chim. Acta, 1976, 59, 19972011.

25 J. Frelek, N. Ikekawa, S. Takatsuto and G. Snatzke, Chirality, 1997, 9, 578-582.

26 P. K. Agrawall, Phytochemistry, 1992, 31, 3307-3330. 